ONE YEAR LATER: THE EMPLOYMENT EXPERIENCES OF SYRIAN REFUGEES IN THE GREATER TORONTO AREA

\author{
by \\ Sonia Khabra, BA, Simon Fraser University, 2015 \\ A Major Research Paper \\ Presented to Ryerson University \\ in partial fulfillment of the requirements for the degree of \\ Master of Arts \\ in the program of \\ Immigration and Settlement Studies
}

Toronto, Ontario, Canada, 2017

(C) Sonia Khabra 2017 


\section{AUTHOR'S DECLARATION FOR ELECTRONIC SUBMISSION OF A MAJOR RESEARCH PAPER (MRP)}

I hereby declare that I am the sole author of this Major Research Paper. This is a true copy of the MRP, including any required final revisions.

I authorize Ryerson University to lend this MRP to other institutions or individuals for the purpose of scholarly research.

I further authorize Ryerson University to reproduce this MRP by photocopying or by other means, in total or in part, at the request of other institutions or individuals for the purpose of scholarly research.

I understand that my MRP may be made electronically available to the public. 


\title{
ONE YEAR LATER: THE EMPLOYMENT EXPERIENCES OF SYRIAN REFUGEES IN THE GREATER TORONTO AREA
}

\author{
Sonia Khabra \\ Master of Arts 2017 \\ Immigration and Settlement Studies \\ Ryerson University
}

\begin{abstract}
This qualitative study explores the employment experiences of Syrian refugees one year after their arrival in Canada through a segmented labour market and different forms of capital framework. Ten Syrian refugees and 3 key informants were interviewed to explore Syrian refugees' barriers to employment, support channels, employment outcomes, and future career goals in Canada. The findings of this study show that insufficient English skills, lack of Canadian work experience, poor mental health, and a limited understanding of the Canadian labour market are the greatest challenges these Syrian refugees encountered accessing the labour market. Privately sponsored refugees were more likely to be employed than government-assisted refugees. Overall, Syrian refugees are in need of greater support from the government to help promote successful economic integration.
\end{abstract}

Keywords: Syrian refugees, employment outcomes, privately sponsored refugees, government assisted refugees, segmented labour market, forms of capital 


\section{Acknowledgements}

There are many individuals and groups to thank for giving me such wonderful support.

Firstly, thank you to KPMG for providing me with funding as it gave me the means to expand and conduct the necessary research required for this topic. Secondly, Saad ElHakmi not only was an excellent translator and interviewer, but also an incredible help in uncovering the themes found in this paper. Thirdly, to the Syrian Refugee Roundtable for showing an interest in my research, assisting me with recruitment, and providing moral support. Lastly, thank you to Dr. Mehrunnisa Ali and Dr. Harald Bauder for your expertise and offering me invaluable feedback. 


\section{AUTHOR'S DECLARATION FOR ELECTRONIC SUBMISSION OF A MAJOR

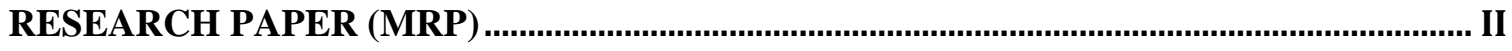

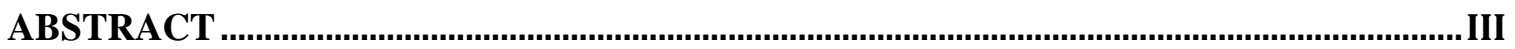

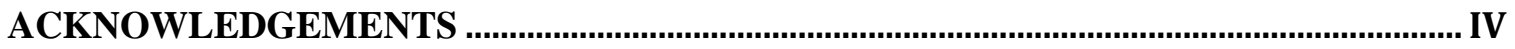

INTRODUCTION

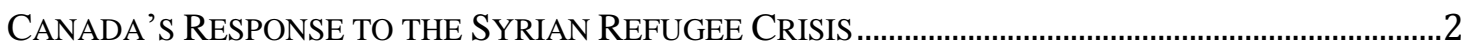

SYRIAN REFUGEE POPULATION IN THE GREATER TORONTO AREA........................................................

THEORETICAL FRAMEWORKS: SEGMENTED LABOUR MARKET THEORY AND

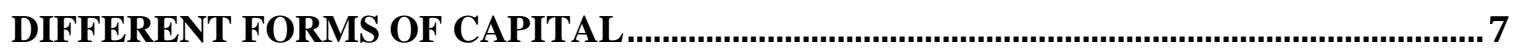

ECONOMIC EXPERIENCES OF REFUGEES IN CANADA .......................................... 12

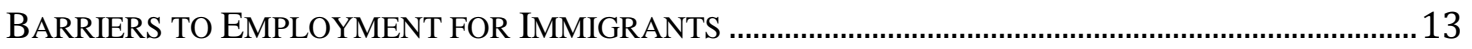

REFUGEES COMPARED TO OTHER IMMIGRANT CATEGORIES ……..............................................15

PRIVATELY SPONSORED REFUGEES AND GOVERNMENT ASSISTED REFUGEES .............................18

METHODOLOGY

SAMPLE

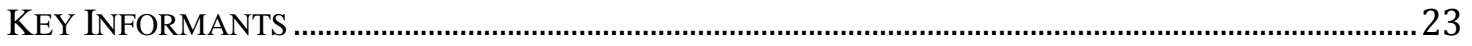

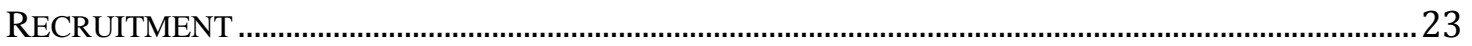

PROCEDURE

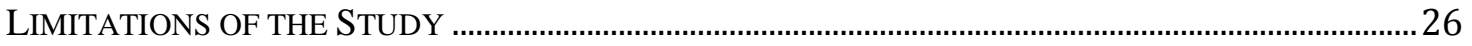

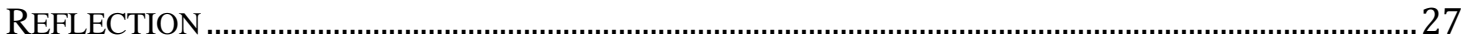

FINDINGS

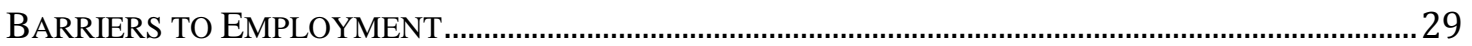

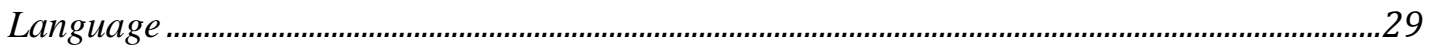

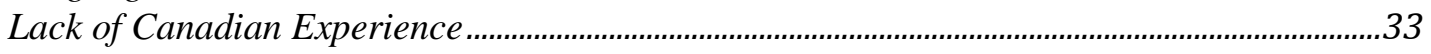

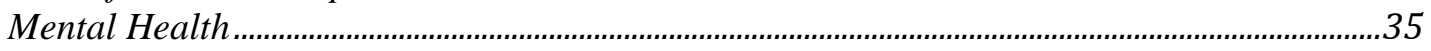

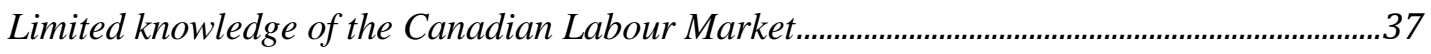

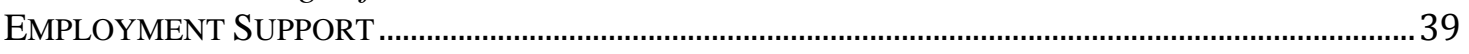

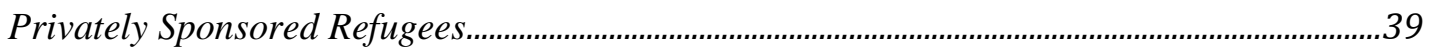

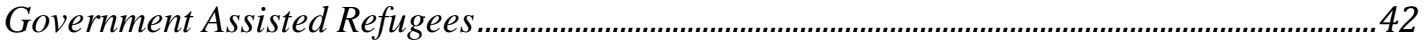

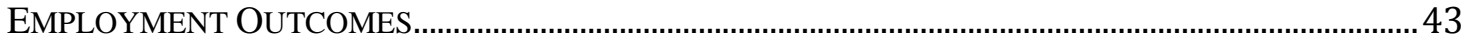

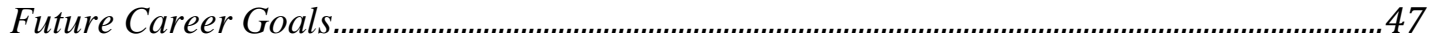

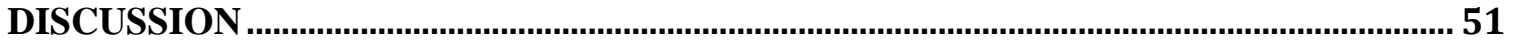

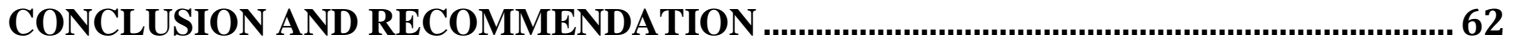

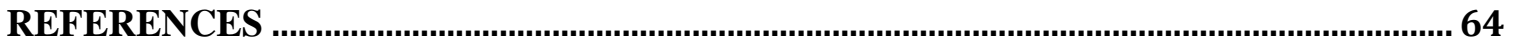




\section{Introduction}

In the year 2016 Canada welcomed 46, 321 Syrian refugees (Puzic, 2017). The resettlement of these newcomers was met with fanfare and extensive media coverage. News outlets reported on eager Canadians, including Prime Minister Justin Trudeau, greeting Syrian refugees at airports across the country. Internationally, Canada's resettlement programs were applauded and stories of Syrians experiencing Canada's cold winter for the first time made headlines. Now, a year later, that attention has decreased. Although Syrian refugees are no longer in the spotlight, the next step in their settlement is equally as important as the previous. Ted Richmond and John Shields (2005) state that settlement is a life long process that takes place in three steps:

The first stage of initial reception (information and referral, language training, short-term shelter, etc.)... The middle stage of the process, which involves securing long-term access to appropriate employment and housing, education, and so forth for all members of the newcomers' families... In the third stage newcomers develop some sense of attachment or belonging in Canada without giving up their ethno-racial identities and their times to their homelands. (p. 516)

A year after their arrival the initial stage of settlement for Syrian refugees has ended. As they move into the middle stage of the settlement process they encounter a major challenge: after a year in Canada financial support from private sponsors and the designated support for refugees from the Government of Canada comes to an end. Therefore, securing employment in the middle stage of their settlement becomes even more important as Syrian refugees must find a way to provide for themselves financially. 
The main questions this study explores are: Have Syrian refugees found employment? If so, what types of jobs are they doing and where have they found employment support? If not, what barriers did they encounter? Looking forward, what are their employment-related aspirations and how Syrian refugees be helped?

\section{Canada's Response to the Syrian Refugee Crisis}

The conflict in Syria between the government of Bashar al-Assad and various other forces began in the spring of 2011 and continues to cause displacement of Syrians today. The United Nations Commissioner for Human Rights, Zeid Ra'ad Al Hussein, stated that the conflict in Syria is the "worst man-made disaster the world has seen since World War II" (United Nations News Centre, 2017). Statistics show that in a country of 22 million people, approximately 7.6 million had been internally displaced and 3.7 million had left the country by the end of 2014 (UNHCR, 2015). By 2015 the Syrian civil war had claimed over 200,000 casualties, including more than 8,000 documented killings of children less than eighteen years of age (UNHCR, 2015). In the year 2014, 70,000 Syrians were fleeing their country every month (UNHCR, 2015). Although that number has since decreased, the regional crisis is not subsiding, "especially as it becomes clear that returning to Syria will not be a viable option in the short or medium term" (Berti, 2015, p.41).

Canada has a long history of responding to refugee crises. John McCallum, former Minister of Immigration, Refugees and Citizenship describes it as "one embedded in our country's DNA” (McCallum, 2016, p.8). However, Canada had a slow and delayed response to the Syrian refugee crisis. By the end of 2014, only 1,285 Syrians had received refugee status in Canada (Mas, 2015). Stephen Harper's Conservative government had 
pledged to accept 10, 000 Syrian refugees between 2015 and 2017 (Mas, 2015).

Canadians began to advocate the government to do more when images of a drowned three year-old Syrian refugee, named Alan Kurdi, made headlines on September 3, 2015. Kurdi and his family had drowned during their crossing by boat to Turkey. They had been trying to come to Canada. The death of Alan Kurdi and his family marked a turning point in Canadian attitudes as Canadians, "came to realized that the 'refugee crisis' was not merely a European problem, but rather that there is a direct relationship between the lack of options that refugees have and their willingness to take desperate measures" (Winter \& Zyla, 2016, p.11). As a result, when Justin Trudeau's Liberal government was elected in October 2015, it promised to help resettle 25,000 refugees by the end of 2015. It reached it's goal on February $27^{\text {th }}, 2016$ (CBC News, 2016).

All refugees who receive resettlement assistance arrived under three different programs: government assisted refugees (GARs), private sponsorship refugees (PSRs), or blended-visa office referred (BVOR) refugees. The Government of Canada or the province of Quebec financially supports GARs during their first year in Canada (CIC, 2017). PSRs are supported by a voluntary group of people in Canada. The sponsorship group is formally obligated to help the refugees find a place to live, and provide financial, emotional, social support, food and clothing, etc. (CIC, 2017). Historically, religious organizations, like the Canadian Christian Council for the Resettlement of Refugees and the National Inter-Faith Immigration Committee had been acting as private sponsors before the 1976 Immigrant Act formally created a private sponsorship program. The private sponsorship program was originally intended to "formalize the already occurring sponsorship of known individuals" (Labman, 2016, p.69). Shortly, after the 1976 
Immigrant Act came into place, the Indochinese "boat people" crisis began, which resulted in private sponsorship shifting from the resettlement of known individuals to "primarily a sponsorship of strangers" (Labman, 2016, p.69). This shift can be seen with regards to private sponsors and Syrian refuges as well. BVORs are a mix of both private sponsorship support and government support. The government gives six months of financial support, and the private sponsorship group gives another six months of financial support, as well as a year of social and emotional support (CIC, 2017). All three categories provide support for one year or until the refugee(s) can support themselves, whichever comes first (CIC, 2017). Syrian refugees become eligible for social assistance one year after their arrival if they are in need of continued financial support. Quebec has its own process for sponsoring refugees.

Canadians generously contributed to the resettlement process of Syrian refugees.

Over a third of Syrian refugees who came to Canada were PSRs (CIC, 2017). In Quebec, alone, 80 per cent of Syrian refugees arrived as PSRs (IRCC, 2017). In total, approximately 350 cities and towns across Canada, not including Quebec, welcomed Syrian refugees (CIC, 2017).

\section{Syrian Refugee Population in the Greater Toronto Area}

The majority of Syrian refugees arrived in Canada between November 2015 and November 2016 (IRCC, 2017). The largest resettlement of Syrian refugees took place in Ontario. The Greater Toronto Area (GTA), alone, welcomed 6, 805 Syrians (IRCC, 2017). Many Syrian refugees visited YMCA Language Assessment Centres in Toronto to assess their English language skills upon arrival (Magnet, 2017). The YMCA GTA collected the demographic, educational, and employment backgrounds of their clients. 
They shared the raw data of 2,109 Syrian refugees with Magnet, a not-for-profit social initiative co-founded by Ryerson University and the Ontario Chamber of Commerce which works to eradicate youth and new immigrant unemployment, and produced a report entitled "Syrian Refugees: Understanding the Depth of Highly Skilled Talent." The report provides vital information on identifying Toronto's Syrian refugee population.

The YMCA GTA data shows that that 65 per cent of the Syrian refugee population in the GTA is PSRs, 27 per cent are GARs, and 8 per cent arrived through blended sponsorship (Magnet, 2017). Sixty-five per cent of Syrians had eight or more years of education (secondary and post-secondary) (Magnet, 2017). The top three occupations Syrian refugees who arrived in Toronto held in Syria are: sales and services occupations (26 per cent), trades, transport, equipment operators and related occupations (22 per cent), and occupations in education, law, and social, community, and government organizations (15 per cent) (Magnet, 2017). Language ability greatly varied among Syrian refugees. English standards are set by the Canadian language benchmarks (CLB). The CLB is measured in three stages: Levels 1-4 represent basic language ability, levels 5-8 represent intermediated language ability, and levels 9-12 represent advanced language ability. The majority of Syrian refugees in the GTA had very limited English skills as, $24 \%$ of the newcomers spoke no English, while approximately $50 \%$ spoke below a level 2. Only $21 \%$ of Syrian refugees spoke at level 5 or higher.

This data shows that the Syrian refugee population in the GTA has a diverse range of education, work experience and English fluency. Each individual Syrian refugee has their own unique experiences in different sectors of the labour market and various amounts of human, social, and cultural capital. In the following section segmented labour 
market theory and different forms of capital are expanded on to provide a framework for the findings and analysis of this research. 


\section{Theoretical Frameworks: Segmented Labour Market Theory and Different Forms of Capital}

This paper employs two theoretical frameworks: segmented labour market theory and different forms of capital. Different forms of capital theories are emphasized throughout the paper as they help to inform why immigrants may be at a disadvantage in the Canadian labour market. Aspects of segmented labour market theory are used to explain how Syrian refugees' employment outcomes are similar to those of other immigrants in Canada. Segmented labour market theory states that the labour market is split into primary and secondary segments (Clairmont, Apostle \& Kreckel, 1983). In the primary sector work is stable, pays well, and offers upward mobility, whereas in the secondary segment it is unstable, with low pay, poor working conditions, and limited upward mobility (Lusis \& Bauder, 2010). Work in the secondary segment can also be categorized as "survival work". This term refers to "jobs that are low-skilled, low-wage, insecure, contingent forms of employment; work that usually did not provide an adequate minimal standard of living" and "experiences of downward mobility and class dislocation when contrasting present circumstances with occupations and status prior to migration, and with expectations participants had for their new lives in Canada" (Creese \& Wiebe, 2009, p.62). Although the two segments depend on each other, the boundaries of the segments are rigid making it difficult to transition from the secondary segment to the primary segment (Lusis \& Bauder, 2010). Segmented labour market theory represents a wider political-economy framework of labour market regulation, which argues that "immigrant labour is subjected not only to forces of market exchange, but also to 
structural relations and processes of social reproduction and cultural distinction" (Bauder \& Jayaraman, 2014, p.178).

In the Canadian context, immigrants are excluded from primary segment occupations by institutionalized cultural practices of credential non-recognition (Girard $\&$ Bauder, 2007) and by expected limited understanding of cultural conventions and performances of professional conduct within Canada (Bauder, 2005). Although, Syrian refugees may have occupied positions in the primary sector previously in Syria, their skills do not always lead to similar positions in Canada. Harald Bauder and Sita Jayaraman (2014) suggest that the, "deskilling and the devaluation of immigrant labour often present immigrants with no employment options in the primary segment (...) relegating them instead to the secondary segment" (p.178). Once in secondary segment occupations it is very difficult for workers to move into the primary segment. Jamie Peck (1996) finds that workers in the secondary segment will likely remain there. Bauder and Jayaraman state that, "immigrants who are allocated to the secondary labor market segment in their initial settlement period often have difficulties advancing their careers and moving into upper-segment occupations" (p.178).

Different forms of capital: human capital, social capital, and cultural capital can impact the employment experiences of Syrian refugees. Many scholars have debated the definitions of various forms of capital, but this paper does not delve into those debates. For operational purposes, this paper relies on four theorists to define the aforementioned forms of capital: James Coleman's (1988) and Robert Putman's (2000) definitions of social capital, as well as Pierre Bordieu's (1986) and Gary Becker's (1962) writings on cultural capital and human capital are utilized. 
Coleman (1988) describes social capital as the obligations, information channels, and norms acquired by one from his or her network. For Coleman obligations are seen as "If $A$ does something for $B$ and trusts $B$ to reciprocate in the future, this establishes an expectation in $A$ and an obligation on the part of $B$ " (p.102). This form of social capital is dependent on two elements: trustworthiness, to ensure the obligations will be repaid, and the extent of obligations held (Coleman, 1988). Coleman states that information is important in "providing a basis for action" (p.104). This resource refers to how people acquire information from their social networks. Lastly, Coleman describes that norms are an important part of social capital, as they encourage people to help one another. In addition, Putnam (2000) builds on this definition as he describes two forms of social capital: bridging and bonding. Bridging capital refers to associations that bring people together from cross-sections of society and bonding capital is associated with closed networks, mainly with people from the same background (Putnam, 2000). Putnam emphasizes social organizational features that include trust, norms, and networks when describing social capital.

Bordieu (1986) believes that cultural capital is one of three different forms of capital. For Bordieu cultural capital refers to "the long-lasting dispositions of the mind and body" in the embodied, objectified, and institutionalized states (p.47). Embodied capital can be seen as knowledge, skills, language and behaviours that are entrenched in an individual or within a group. Objectified cultural capital refers to "cultural goods such as pictures, books, dictionaries, instruments, machines, etc.” (Bordieu, 1986, p.47). Lastly, institutionalized cultural capital refers to educational achievements "sanctioned by legally guaranteed qualifications", that give it's holder "legally guaranteed value" 
(Bordieu, 1986, p.88). In sum, cultural capital includes, "the verbal facility, aesthetic preferences, artifacts, attitudes, beliefs, educational credentials, values, tastes, and behaviors of an individual or group, which differ from those of other individuals and groups" (Bourdieu, 2011, as cited by Brar, 2016, p. 54).

Becker (1962) popularized the term human capital, which means "activities that influence future real income through the imbedding of resources in people" (p.9). Becker explains that there are many ways to invest in human capital including schooling, on-thejob training, medical care, vitamin consumption, and learning about the economic system. These investments impact wage earnings and therefore tangible forms of capital, like a bank account or house, are not the only form of capital that should be valued. Unlike, physical forms of capital, like real estate, or cars, people cannot be separated from their knowledge, health, or skills in the way they can be from their financial and physical assets (Becker, 1962). Although, health, which includes mental health, as human capital is under-researched it is an important component of human capital as well. Becker's (2007) study on health as human capital found that "persons with better survivorship probabilities", chances of longer life expectancy, "tend to get more education and hence have higher earnings" (p. 408). Thus, it is advantageous for those entering the workforce to have good overall health.

Newcomers to Canada are at a disadvantage immediately upon arrival, as not all forms of capital are transferrable from one context to another. They find themselves starting off in a new country with very little social, human, and cultural capital. Therefore, as Gillian Creese and Brandy Weibe (2009) explain "immigrants must negotiate unfamiliar labour practices without the same social or cultural capital that 
native-born workers take for granted" (p.59). Harris Hyun-soo Kim (2017) states that since an immigrant's origin-country human capital "is not easily transferrable or less valued in the host country, immigrants invest in building and utilizing social capital embedded in their co-ethnic communities and family contexts to deal with labor market challenges" (p.185). Social capital is particularly important for labour market outcomes because it can offer informal exchanges of information, introductions, and vouching for a person's character (Kim, 2017). Moreover, social networks can connect immigrants to jobs in the different labour market segments (Waldinger, 1995). For example, bridging capital can lead immigrants to work in the upper segments of the labour market, as Canadian- born individuals will more likely have useful information that can connect immigrants to better employment opportunities and away from "survival work" (Briggs, 1998). 


\section{Economic Experiences of Refugees in Canada}

While a fairly large body of empirical research and policy documents exists on immigrant employment outcomes in Canada, studies on the economic experiences of refugees are scarce. Very few Canadian studies on refugees have a truly national scope or contain systematic empirical analyses, and many are limited to reporting on one specific refugee community. Soojin Yu, Estelle Ouellet, and Angelyn Warmington (2007) argue that there are at minimum two reasons why refugee integration issues may differ from other immigrant groups, and warrant more academic research. First, refugees are admitted into Canada on humanitarian as opposed to economic grounds:

The key selection criterion for immigrants is their ability to establish: economic potential for the principal skilled worker and business applicants, and the presence of economic and social supports in Canada for family class. In contrast, the primary consideration for refugees is their need for Canada's protection. Given this difference at the selection stage, it is not unrealistic to expect different patterns of integration between refugees and immigrants. (p. 18)

Second, it is likely that a refugee's migration experience is more traumatic than voluntary immigrants (Yu et al., 2007). The trauma surrounding their migration may impact integration patterns and call for more specialized services, including mental health care and counseling, in addition to the generic integration services. Thus, research focusing particularly on the labour market outcomes of refugees in Canada is needed to promote their successful economic integration. 


\section{Barriers to Employment for Immigrants}

Employment is seen as an important pathway to integration (Hynie \& Changoor, 2016). Economic integration is "considered to have occurred when immigrants catch up to or surpass the labour market earnings profile of the native-born population" (Shields, 2003, p. 22). Employment can impact many aspects of an immigrant's life such as: "promoting economic independence, planning for the future, meeting members of the host society, providing opportunity to develop language skills, restoring self-esteem and encouraging self-reliance” (Ager \& Strang, 2008, p.170). As such, labour market outcomes are an important step in the integration process for newcomers. However, employment experiences are complex as various factors influence labour market outcomes, most notably: Canadian work experience, foreign credentials, and language proficiency. First, these factors, regarding all immigrant categories, are explored. Then, it is shown how these barriers affect refugees to an even greater extent.

The literature shows labour market entry to be the most difficult task for immigrants, as there is high turnover and employment tends to be at a lower skill levels then anticipated. Factors such as high levels of education, foreign work experience in one's intended occupation, and a high level of proficiency in English or French enable immigrants to obtain job matches more quickly that others (Frank, 2013). However, the most commonly reported problems are lack of Canadian job experience, lack of recognition for foreign credentials or experience, and lack of official language proficiency (Reitz, 2007).

While more recent cohorts of immigrants are highly educated, foreign education and experience is strongly devalued in the Canadian labour market (Ferrer \& Riddell, 2008). However, foreign education is still rewarded when compared to immigrants with 
lower levels of education as those with a university degree higher than a Bachelor's do obtain job matches more quickly than those with only a Bachelor's degree (Frank, 2013). Peter Li's (2008) analysis of the Ethnic Diversity Survey finds that race and gender play a substantial role in affecting labour market outcomes for immigrants when foreign credentials are considered. White immigrant men and women with foreign credentials earn more than immigrants of a visible minority background with similar foreign credentials.

Harald Bauder (2003) expands on these findings by arguing that regulatory institutions actively exclude immigrants from obtaining highly desired jobs. He states that professional associations and employers give preference to Canadian-born and educated workers by devaluing foreign credentials by asking potential employees to demonstrate Canadian work experience (Bauder, 2003). Due to these challenges, "immigrants suffer from occupational downgrading, are forced to switch careers and experience loss of social status" (Bauder, 2003, p.713). The de-skilling of highly educated and skilled immigrants results in "brain abuse", which is a loss of human capital for both Canada and the origin country (Bauder, 2003).

Language limitations also have a substantial impact on employment outcomes for immigrants. Chantal Grondin (2005) states, "when immigrants arrive in a new country, their ability to express themselves in the official language or languages of that country can have a major impact on how successfully they integrate" (p.7). Language ability is one of the main components of human capital and is "undeniably a major economic asset" (Grondin, 2005, p.7). Monica Boyd and Xingshan Cao (2009) found that immigrants with poor destination country language skills earn less than those who are 
proficient in the national languages. The earning gap is greatest for immigrants in well paying jobs (Boyd \& Cao, 2009). Lastly, lack of fluency in the national language particularly affects women, as female immigrants are less likely to be proficient in English or French (Boyd and Pikkov, 2005).

\section{Refugees Compared to Other Immigrant Categories}

Refugees share barriers to employment similar to those faced by other immigrants, such as lack of official language skills, lack of Canadian work experience, difficulty in foreign credential recognition, and racial discrimination. However, these barriers are more common and intensified for refugees compared to voluntary immigrants. Yu et al.'s (2007) analysis of Canada's Immigration Database shows that refugees have a poorer self-assessment of official language skills upon landing compared to other immigrant categories. According to this study, $69 \%$ of resettled refugees are unable to speak French or English upon arriving, compared to $36 \%$ of other immigrant categories (Yu et al., 2007). However, refugees are much more likely than other immigrant groups perhaps due to their poor language skills upon arrival, to receive language training within six months of arrival: $57 \%$ of refugees compared to $24 \%$ of family class immigrants, $25 \%$ of skilled workers, and $30 \%$ of all immigrant categories, attend language classes (Yu et al., 2007). The aforementioned data collected from the YMCA GTA on Syrian refugees reflects Yu et al.'s findings. Further, resettled refugees arrive with a low level of formal education. Yu and colleagues point out that low educational attainment is often directly linked to low economic outcomes. They state, "a low level of formal education can affect economic outcome indirectly too, as it negatively 
affects one's ability to acquire an official language, which is a prerequisite for successful employment in Canada" (Yu et al., 2007, p. 22).

Randal Montgomery's (1986) survey of 537 Vietnamese refugees living in Alberta had similar findings. Montgomery concluded that refugees experience lower levels of mobility compared to other immigrant groups as a result of lower levels of fluency in English, educational credentials and Canadian experience. Consequently, under-employment, defined as holding a job, which does not require the level of skills or qualifications possessed by the jobholder, is a major issue that refugees face in the labour market (Africa Educational Trust 1998 as cited in Ager \& Strang, 2008).

Furthermore, refugee youth also face higher levels of unemployment when compared with other immigrant groups (Wilkinson, 2008). Michaela Hynie and Tina Changor (2016) explain that, "the nature of forced migration means that refugee youth often experience frequent and/or prolonged disruption of education, and education opportunities in refugee camps can be limited and/or difficult to access“" (p.32). Therefore, their higher levels of unemployment may be due to lower levels of education for their age relative to non-refugee immigrants (Shayka, Guruge, Hynie, Akbari, Malik, Htoo \& Alley, 2012).

Immigrants who arrive in Canada under the family class and refugee categories are often compared as both groups are accepted into Canada due to reasons other then economic grounds. Aydemir (2011) concluded that refugees have lower participation rates in the labour market compared to family class immigrants, but their earnings are about the same. However, Pieter Bevelander and Ravi Pendakur (2014) argue that despite the social and psychological disadvantage refugees encounter, their access to settlement 
services allow them to perform better than family class immigrants. They found that earnings for refugee women are higher than earnings for family class women, while earnings for refugee men are about the same as those for family class men (Bevelander $\&$ Pendakur, 2014).

Mental health is also an important factor to consider when comparing the employment outcomes of refugees to other immigration categories, as health is a type of human capital (Becker, 2007). Colborne (2015) states it is impossible to ignore the impact of war on Syrian refugees' mental health. The central mental health issues in an armed conflict setting are loss and grief, whether for missing or deceased family members or for other emotional, relational and material losses (Hassan, Ventevogel, Jefee-Bahloul, Barkil-Oteo \& Kirmayer, 2016). A significant source of stress is the concern about safety for family members still living in armed conflict (Hassan et al., 2016). Furthermore, Moussa (2014) states that refugees may have feelings of estrangement, and yearning for their homeland. Displaced Syrians may struggle to adapt to life as refugees within a foreign community resulting in a loss of identity (Moussa, 2014).

The World Health Organization recognizes the ability to find productive work as a key element of mental health and well-being (WHO, 2014). There is substantial evidence that unemployment among refugees negatively impacts social, mental and physical health outcomes (Reitmanova \& Gustafson, 2008). Michaela Hynie and Tina Changoor (2016) point out that it is not solely employment that matters, but also the quality of employment. Research finds negative health outcomes associated with poor quality employment where it involves more physical demanding work (Hynie \& 
Changoor, 2016). Moreover, working in a job that is not commensurate with training and education also has psychological consequences (Hynie \& Changoor, 2016). Labour segmentation theorists argue that immigrants are excluded from the primary segment of the labour market and delegated to the secondary segment where poor quality employment and deskilling is most prevalent.

Some evidence suggests that for refugees to successfully integrate they must have access to programs to assist them (Ager \& Strang, 2008; Hynie \& Changoor, 2016). It is important to note that most refugees are tremendously resilient and programs to support refugees must "work on establishing the conditions that promote such resiliency" (Hassan et al., 2016, p.131). For example, vocational training along with further education can help foster employability through enhancing language and work skills (Ager \& Strang, 2008). Ager \& Strang (2008) state that providing refugees with support can also help the host country: "In areas with significant potential for economic growth and a demand for labour such efforts, crucially, can be seen to be not only to the benefit of refugees and their families, but to the wider communities in which they may settle" (p.171). In addition, access to mental health services should be considered equally as important as access to employment services.

\section{Privately Sponsored Refugees and Government Assisted Refugees}

Although Canada's resettlement programs have guided the resettlement of refugees for many years, little information is available about the differences between GARs and PSRs. In the literature BVORs are rarely differentiated between the three programs, which points to the need for more research about them. IRCC's January 2017 ministerial briefing document revealed that all Syrian refugees face challenges in 
accessing employment, however, "the outcomes for different programs is stark" (Malcolm, 2017). There is a large gap between PSRs and GARs regarding their employment experiences. Statistics collected by IRCC in 2017 show that 53\% of PSRs have been able to find work, compared to only 10\% of GARs (Malcolm, 2017). Indicating that nine out of ten government assisted Syrian refugees are unemployed (Malcolm, 2017). One of the reasons this may be is due to the language barrier. Only $17 \%$ of GARs had basic English skills, while by contrast $81 \%$ of PSRs had knowledge of one of Canada's official languages (Malcolm, 2017). Furthermore, PSRs may have a head start, as their sponsorship groups are able to provide direct and personal support, while GARs are left to rely on the "depleted resources of the government" (Malcolm, 2017). The findings on the differences between Syrian GARs and PSRs are not surprising, as the limited pre-existing literature has shown that historically PSRs have much better employment outcomes compared to GARs.

Morton Beiser (2003) used data from the University of Toronto's Resettlement Project, a 10 year study of resettlement of more than 1300 Southeast Asian refugees admitted to Canada during 1979-1981, to analyze employment outcomes for refugees. 608 refugees were interviewed at 3 points in time from 1981 to 1991 . He found that private sponsorship predicted successful integration whereas government sponsorship was more likely to predict the opposite. Indicating that private sponsorship may make a significant contribution to long-term successful integration of refugees.

The literature reviewed in this section helped to inform the methodological approach for this study in two main ways. First, as refugees are a more under-researched immigrant group compared to other immigration categories Syrian refugees were chosen 
to be the sample. Second, the studies reviewed in this section have been predominately quantitative works. To expand the type of research available on the topic of refugees a qualitative approach was chosen for this study. The following section goes into greater detail about why a qualitative methodological approach was utilized for this research. 


\section{Methodology}

I chose to conduct a qualitative study, as qualitative analysis allows for an "indepth study of a relatively focused area" (Denscombe, 2010, p.304). Research published on the economic experiences of Syrian refugees thus far has primarily been focused on statistics and figures collected by the government of Canada (Malcolm, 2017; IRCC, 2017), which fail to address the complexities regarding the refugee resettlement experience from the perspective of the refugees. A qualitative approach is able to "make visible and unpack the mechanisms which link particular variables, by looking at the explanations, or accounts, provided by those involved" (Rosaline, 2017, p.4). As such, the "everyday practices, interactions, and understandings" shared by the participants of this study help to provide a greater understanding of the statistics collected on the employment outcomes of Syrian refugees (Rosaline, 2017, p.4). Furthermore, as "quantitative research tends to favour larger scale research with larger numbers and greater quantities" a qualitative approach was more favourable as this is a small-scale study, due to limitations on time and resources available (Denscombe, 2010, p.237).

\section{Sample}

This study's intent is to gain an in-depth understanding of all aspects of employment regarding Syrian refugees, including those who are employed, unemployed and actively pursuing work, or unemployed and not pursuing work. The last category was included to see why some may not want to seek employment, which might potentially illuminate specific barriers to employment that those who are working or looking for work might not experience. All participants interviewed had been living in Canada for 8 months to 1.5 years and were of the adult working age population, 18 years and older. 
The two BVOR refugees in this study received the same type of assistance from their private sponsors as the PSRs did. As such, throughout the remainder of this study they are referred to as PSRs. Table 1 shows the demographic profile of the participants.

Many Syrian refugees arrived in Canada with little to no English language skills. As shown in the literature review immigrants who cannot speak one of Canada's official languages have a harder time finding employment. I did not want to restrict my sample to solely English-speaking Syrian refugees and neglect the voices of non-English speaking Syrians, as their employment experiences might be different. However, as a non-Arabic speaking researcher I could not communicate with them. I was able to mitigate this issue by hiring an Arabic-speaking interviewer, Saad El-Hakmi, a Masters student at Ryerson University's Immigration and Settlement Studies program. El- Hakmi was hired to interview Arabic-speaking Syrian refugees, and to translate the interviews conducted in Arabic into English. The inclusion of non-English speaking participants allowed for a richer study. 
Table 1. Demographic Information

\begin{tabular}{|l|l|l|l|l|l|l|}
\hline Code Name & $\begin{array}{l}\text { Refugee } \\
\text { Type }\end{array}$ & $\begin{array}{l}\text { Language } \\
\text { of Interview }\end{array}$ & Sex & $\begin{array}{l}\text { Previous } \\
\text { Occupation } \\
\text { in Syria }\end{array}$ & $\begin{array}{l}\text { Current } \\
\text { Occupation } \\
\text { Status }\end{array}$ & $\begin{array}{l}\text { Type of } \\
\text { Occupation/ } \\
\text { Activity }\end{array}$ \\
\hline Participant 1 & PSR & English & Male & $\begin{array}{l}\text { Humanitarian } \\
\text { Sector }\end{array}$ & $\begin{array}{l}\text { Employed } \\
\text { Academic } \\
\text { Counselor for } \\
\text { International } \\
\text { Students }\end{array}$ \\
\hline Participant 2 & PSR & English & Female & Unemployed & Employed & $\begin{array}{l}\text { Administrative } \\
\text { Assistant at a } \\
\text { School }\end{array}$ \\
\hline Participant 3 & BVOR & English & Female & Nurse & $\begin{array}{l}\text { Non- } \\
\text { employed }\end{array}$ & Student \\
\hline Participant 4 & GAR & English & Female & Law Student & Unemployed & N/A \\
\hline Participant 5 & BVOR & Arabic & Male & $\begin{array}{l}\text { Business } \\
\text { owner of a } \\
\text { fruit and } \\
\text { vegetable } \\
\text { market }\end{array}$ & $\begin{array}{l}\text { Employed } \\
\text { (part-time) }\end{array}$ & Bakery \\
\hline Participant 6 & PSR & Arabic & Male & $\begin{array}{l}\text { Engineering } \\
\text { Student }\end{array}$ & Employed & Line Cook \\
\hline Participant 7 & PSR & Arabic & Male & $\begin{array}{l}\text { High School } \\
\text { Student }\end{array}$ & Unemployed & N/A \\
\hline Participant 8 & GAR & Arabic & Female & $\begin{array}{l}\text { High School } \\
\text { Student }\end{array}$ & Unemployed & Student \\
\hline Participant 9 & GAR & Arabic & Female & $\begin{array}{l}\text { High School } \\
\text { Student }\end{array}$ & Unemployed & Student \\
\hline Participant 10 & GAR & Arabic & Male & Painter & Unemployed & Student \\
\hline & & & & & & \\
\hline
\end{tabular}

\section{Key Informants}

Key informants were included in this study for two main reasons: to provide their perspectives on the challenges that Syrian refugees experience while searching for employment, and share how they have offered employment support. Three key informants were interviewed. All have over one year of experience as a frontline settlement worker assisting Syrian refugees find work. Each service provider was from a different organization, ranging from fairly small to large.

\section{Recruitment}

Participants were recruited through two methods. The first method involved two different organizations sending an advertisement for recruitment via e-mail to all their 
clients and staff. One of the organizations worked indirectly with Syrian refugees. This organization assisted private sponsors with sponsoring Syrian refugees, and provided support to the private sponsors after the PSRs had arrived. The second organization is a non-profit that focuses on helping Syrian refugees find employment. For the second recruitment method snowball sampling was used. This involved asking participants who were interviewed if they knew anyone, who fit the recruitment criteria, and may be interested in participating in the study.

Participants were provided with a $\$ 20$ incentive to encourage participation. They were also reimbursed up to $\$ 10$ for transportation costs. Syrian refugees had the option to be reimbursed up to $\$ 60$ for childcare costs. However, no participant asked to be reimbursed for childcare costs. Participants were informed that if they chose to withdraw at any time during the interview incentives and reimbursements would still be given.

It was important that Syrian refugees who participated in the study did not feel pressured to participate by the organizations helping with recruitment or their private sponsors, and aware of the potential risks and potential benefits involved. All participants were provided with consent forms ahead of the interview to review. Consent forms for Syrian refugees were available in English and Arabic. The consent form and recruitment advertisement emphasized that refusal or acceptance of participation would not impact the relationship between the organization that emailed the recruitment advertisement, Ryerson University, or the researchers involved. Approval for this research was granted from Ryerson University's Research Ethics Board before any data was collected. 


\section{Procedure}

One-on-one semi-structured interviews were conducted with Syrians refugees and key informants to learn about the employment experiences of Syrian refugees in the GTA. The interviews were carried out in an identical fashion with the exception of a different interview guide. Semi-structured interviews were chosen as the methodology to allow "respondents to focus on the issues of greatest important to them" (Barbour, 2008, p.11). The one-to-one nature of the interviews allowed participants to have greater flexibility as to when they would be available for the interview. The GTA serves as a useful geographical location, because it offers a diversity of Syrian refugees, as it was the city that the largest amount of Syrians resettled in. Purposeful sampling was used to "select individuals... that will be most informative" (McMillan \& Wergin, 2006, p. 95).

All thirteen interviews were audio-recorded and transcribed. Each interview ranged from approximately thirty minutes to one hour. The names of all participants were kept confidential. El-Hakmi only had access to the interviews he conducted and transcribed. My supervisor and I were the only ones who had access to all the data.

I transcribed the interviews conducted in English and El-Hakmi translated and transcribed the interviews conducted in Arabic. We both attempted to transcribe as close to verbatim as possible. After the interviews were transcribed the documents and notes made during the interview were reviewed before data analysis began. Coding was conducted on three levels. Codes refer to "tags or labels that are attached to the 'raw' data" (Denscombe, 2010, p.284). During the first level of coding, open coding, I categorized responses under 10 different themes. Open coding is where the "researcher examines data to condense them into preliminary analytic categories of codes" (Neuman, 2006, p. 461). Next, axial coding followed. Here, codes were linked to key analytical 
categories (Neuman, 2006). The most reoccurring themes were categorized into four

larger sections- barriers to employment, employment support, employment outcomes, and future goals. Lastly, selective coding was done to choose data that supported the conceptual coding categories. Specific quotes that represent the themes most emphasized by participants were selected and appear in the Findings section.

\section{Limitations of the Study}

The most obvious limitation is the risk of mistranslating the audio-recording of the interviews into English from Arabic. Ideally, this risk would have been mitigated through member checking, which means "submitting notes to informants to ensure that their perspectives have been recorded accurately" (McMillian \& Wergin, 2006, p.96). However, this would have entailed El- Hakmi transcribing the interview into Arabic first, sending it to the participant, waiting for their response, and then transcribing it into English. This posed two challenges. Firstly, this would have doubled El- Hakmi's workload, which we unfortunately did not have enough time for. Secondly, due to funding limitations I would not have been able to pay El- Hakmi for this added work.

Another limitation is that I have an outsider perspective. My own positionality as an outsider, who does not belong to the specific group that is being studied influences all aspects of the research process, "from the nature of questions that are asked, through data collection, analysis, and writing, to how findings are received" (Carling, Erdal \& Ezzati, 2014, p.38). This again, might lead to misinterpretation of the data collected. Discussing my findings with my supervisor, who is an experienced researcher with relevant research experience to this specific topic helped to reduce the effects of this challenge. 
Lastly, the study has a small, relatively homogenous sample. It would have benefitted from having a larger, more diverse sample. Missing in my sample are, particularly those who are categorized as "highly skilled". As this is a qualitative study the findings are not generalizable but conceptual transferability is possible. Conceptual transferability is an "imaginative process in which the reader of the research uses information about the particular instance that has been studied to arrive at a judgment about how far it would apply to other comparable instances" (Denscombe, 2010, p.301). Thus future groups of refugees arriving in large numbers may have similar employment experiences as the Syrian refugees. Conceptual transferability might also apply to immigrants in general, who are trying to access Canada's labour market.

\section{Reflection}

Through this research process I learned how important it is for participants being interviewed to completely understand the questions that are asked, and to fully articulate their responses. I found that participants who stated they were able to do the interview in English had difficulty answering some of the questions due to a lack of fluency in English. In retrospect, it would have been better if participants were asked which language they felt they could communicate best in, rather then if they felt comfortable speaking English. The interviews conducted in English were less in-depth, and at times

confusing to understand. As I realized this fairly early, the majority of the interviews with participants were conducted by El-Hakmi in Arabic. Furthermore, it would have been beneficial to interview key informants before beginning interviews with Syrian refugees. This would have helped in drafting research questions, informed my interview guide for Syrian refugees, and provided me with greater context about the employment experiences 
of Syrian refugees in the GTA. Secondly, after review I realized that some of the questions asked during the interviews were leading questions. Although, participants were asked to expand upon their answers they might have felt led to respond in agreement with the question being posed. By providing a reflection on my methodology my aim is to make the findings of this research as transparent as possible with the hope that through acknowledging these shortcomings the reader can have greater clarity. 


\section{Findings}

The finding section is divided into four sub-sections to address the research questions this paper poses: barriers to employment, employment support, employment outcomes, and future career goals. The main barriers to employment that participants expressed were lack of fluency in English, lack of Canadian experience, poor mental health, and a limited understanding of the Canadian labour market. Participants received employment support from mainly settlement agencies, and sponsorship groups. All of those who were employed had jobs in the secondary segment of the labour market. Lastly, all respondents wanted to pursue higher education to improve their current situation; however, they also noted that in order to succeed in Canada greater support is needed from the government.

\section{Barriers to Employment}

\section{Language}

Limited English skills, as a theme, played a dominant role in all the interviews conducted. All participants and key informants agreed that the lack of fluency in English is the number one barrier Syrian refugees encounter during the job search. Settlement agencies place a large focus on English classes. One of the three federal government funded programs settlement agencies provide is Language Instruction for Newcomers (LINC). Classes in the LINC program are based on the official national standards for measuring and recognizing language skills. As such, all participants speak about their English language skills by referencing the CLB levels and have at some point been enrolled in LINC classes. Three participants described why learning English is an important step to securing employment: 
Language plays a crucial role in securing a job here for sure. My sponsor family found me an opportunity at No Frills grocery store, but when I was interviewed the employer told me that my English needs to be improved and that I cannot have the job (Participant 3).

I believe my English level is 4 or 5 which is not that advanced. I faced many difficulties while searching for a job due to the language. The interviews were in English. When I started working for Paramount the manager asked me for my English level to see if he can place me as a server or as a cashier, but my level was not that good so I was asked to work in the kitchen (Participant 4).

I believe that my English is ok but it is not good enough. I am aware that the language is the key factor in looking for a job and the better your English is, the higher your chance of finding a decent job is. I confirm then that English was a significant barrier that prevented me from finding a job here in Canada (Participant 7).

Further, participants felt confident that once they had overcome the language barrier securing a job would not be difficult. When asked if they were worried about finding work after they had become fluent in English many participants said no and stated that finding a job would not be a challenge without the language barrier. Participant 3 and 4 stated,

No, because I heard many jobs you can find easy. You have to be perfect (in) English, you can get job (Participant 3).

If you have the language, and Canadian experience its more easier. You can find job in one hour (Participant 4).

English is seen as such an important factor when looking for work that participants who were fluent in English stated their language ability to be the primary reason they were employed. Participant 2 noted,

In my case language was not a problem. I am a holder of an English degree back home and when I came here I did the English test and scored level 7. If I had a lower level, it would have been of course a barrier for me finding a job here in Canada. Also at the place I work in English is the only language used, so they had chose me because of my language fluency (Participant 2). 
The time it takes participants to improve their English skills greatly varies. Participant 3, a mother of four children, had a difficult time learning English. She decided to not look for work as of now, because she wanted to focus on improving her language skills. Her goal was to become a nurse in Canada, but before she could begin attending a postsecondary institution to upgrade her education she needed to be at a level 6 in English. It has taken Participant 3, one year and three months to move from level 1 to level 3. While, Participant 4 was able to improve her English skills at a much quicker pace. It took Participant 4, an unmarried, young adult, with no children, only six months to move from level 3 to level 6 in the LINC program. Now, because she was at level 6 she felt confident enough in her language ability to begin looking for work.

There are multiple factors that prevented the respondents from learning English. For some it may be too difficult to focus on English classes. One key informant noted that Syrian refugees were being pulled in many directions, particularly in their first year of arrival:

It's taking longer then we expected. A lot of them have been here for a year and a half and they are still at the same level of English, and the reason for that, this group specifically, they have a lot of children, they did not focus. The first year was actually a settlement year they were busy with the settlement, where to live. Is this apartment comfortable? Is this neighbourhood comfortable? Where to find the family doctor, and all those things? They were busy with the settlement. They did not focus on the English classes. They have a lot of kids, they have a lot of doctor's appointments for each child, so they did not move even one step forward in terms of language or training. They stayed at the same level (Key Informant 1).

As Key Informant 1 stated it can be difficult for some newcomers to improve their language skills, because they have other priorities. When Participant 5 was asked if he would want to take English classes he expressed a desire to do so, but noted the challenges it would require him to overcome. He described his age and family as reasons 
why he was not able to attend LINC classes. Although, Participant 5 was receiving social assistance through the Ontario government he stressed that he still felt financial pressure. He stated,

I would love to I did some English classes here but to be honest when you are in a certain age it gets so difficult to learn new things. In addition, I have bills to pay and a family to support, so I can't afford being off income. Although the government is providing me $\$ 1500$ it is not enough to cover all expenses. I sincerely prefer to work and make more than $\$ 1500$ instead of receiving it from the government (Participant 5).

Key Informant 3 explained that unfortunately Participant 5's situation is not unique. Key Informant 3 stated that ideally participants would have an intermediate knowledge of English before pursuing work, but due to the pressure Syrians are facing to find work to support their families they are going into the workforce with a very limited knowledge of English. Key Informant 3 explained that some employers are willing to train newcomers that are not fluent in English, so in those cases they have advised the refugees to prioritize work over improving their English. Key Informant 3 said, When they come in for intake session we require for them to take a Canadian language benchmark test. We require them to be at least level 5 for them to find work. But for Syrian refugees we have been making exceptions. There may be Syrians who are in high-level English classes, but I haven't met one of those highly skilled individuals. I do meet a lot of level $2 s$ and $3 s$. They are passionate, they want to pass, they want to move forward, they want to be able to practice, but its not that easy for them to be able to sail through the classes, as anybody else who would have that little bit of background to sail through the classes, and their older individuals, it's harder to learn, it's harder to start fresh for them. It takes a lot longer. They go home, they speak their own language with their families. They don't get much practice. Level 5 is according to the ministry, the ones we can assist, but we have been making a lot of exceptions for Syrian refugees (Key Informant 3).

Although, there are challenges participants face in taking LINC classes, there can also be some benefits to attending the classes that go beyond improving English language 
skills. Participant 4 was able to learn about immigrant serving agencies from her friends at LINC. Participant 7 also described his English classes as a place where he was able to make friends and learn about employment opportunities. Participant 5 had a similar experience, which he explained as thus:

I was able to connect socially with few people here in Canada. My circle was made of friends at the English school and language exchange program. I asked them for help in terms of looking for a job and they guided me to an employment agency. I went to the work agency and I was assigned with a mentor that started to help me looking for jobs. I also used Internet to look for jobs and it was not easy for me as I felt lost in so much content. I believe that the combination between social networking and specialist's help can be efficient one day (Participant 5).

When asked about why English is so important to prioritize Participant 4 described language as a pathway to independence. She explained that fluency in English allowed her to move away from being dependent on others to help with everyday tasks. However, it also made her family more dependent on her, because they had to rely on her due to her language ability. Participant 4 said,

If you speak English you don't need any help, just you need English (...) it's more important for you to improve your English, because when you don't speak English you can't understand anything. You can't ask about anything, you have to have translator for any appointment and it's more difficult. We have here a lot of appointments, maybe three appointments in the same day (...) Appointments for doctor, family doctor, for meetings at school, you know a lot of appointments everyday. And if you have to have a translator for every appointment it's more difficult, but if you can understand and speak a little English it's going to be fine for your family and for you. Here, I am responsible for my family, because when we came to Canada they can't speak English at all. They didn't know any words in English, just good afternoon and good morning. I was responsible for them. For my brother in high school and my sister, I registered them in high school (Participant 4).

\section{Lack of Canadian Experience}

Participants stressed having Canadian experience as necessary in order to find employment. Those who spoke an intermediate level of English described their lack of 
Canadian experience to be their biggest hurdle in securing work. They claimed that employers viewed their previous work experience and education as unimportant, because it was not acquired in Canada. Participant 1 said,

(...) Here and in the Western world in general, they consider the experiences that we have in the Middle East as nothing to be honest. They will not trust our abilities and our experiences most of the time; I am not generalizing, but this is what happens most of the time. The non-for-profit sector is so competitive here in Canada and especially the management level of it. I used to be a supervisor, then an operation manager in the NGO's I told you about in Lebanon and Turkey. So it is very hard here to jump to the management field if you don't have the Canadian experience. I am searching for an entry level (job) now. Then I will go for the management level after (Participant 1).

Many participants stated having openness to working in any type of job, because they prioritized gaining Canadian work experience over their employment occupation. When

Participant 4 was asked why she did not have a specific job in mind she said,

Because I want to start, just start at work. To learn about the life at work (Participant 4).

Is it more about the experience your getting than a specific job (Interviewer)? Yes. I have to get Canadian experience in any kind of job, and after that I will be specific (in the job I want) (Participant 4).

When participants were asked how they were trying to address the issue of lacking

Canadian experience many stated they took volunteer positions. Participant 9 noted that

he volunteered at a variety of places to gain Canadian experience. However, his

experiences volunteering left him feeling dismayed. He stated,

I strengthened my resume with volunteering experience in many places, such as libraries and YMCA. I was involved in organizing events and doing programs for children. I was teaching people Arabic too in a school in Thorncliffe area. I also found an opening position as cashier in an Afghani restaurant and I asked them to give me a chance to work. They trained me for 3 days working 8 hours per day and they told me they will call me back, but I have never received a response from them. I had a negative experience, because it was so demanding and tiring and on top of that I was not paid (Participant 9). 
Further, the participant stated that volunteering was not helpful in finding him

employment, as employers wanted to see work experience. Thus, leading the participant

to feel that he was trapped in a hopeless situation. Participant 9 noted,

The majority of places I went to looking for jobs asked me about the Canadian experience. Although volunteering looks good on the resume, but employers want to see a paid job on it. I don't really understand this system; I need to get a chance to work first and then to be asked for experience (Participant 9).

\section{Mental Health}

Participants were very forthcoming in detailing their mental health. They spoke

about mental health in two ways: trauma caused by the war in Syria and the stress of their new lives in Canada. Many participants stated that they were suffering from poor mental health, because they were worried about their family and friends in Syria. Participant 7 described his mental well-being:

It is so traumatizing when we hear in the news about the war and people that are killed daily. This situation takes so much of our time in Canada and prevents us from living a normal life. We feel that there is a huge danger around the rest of our families there in Syria and this leaves us with a constant fear. This fear can affect our daily tasks here including looking for jobs, studying or socializing. This is a continuous trauma, but I believe that it starts to disappear slowly once we start adapting to the Canadian life style. When I was in Sudan I was following the news about Syria 4 hours per day, when first I came to Canada it was reduced to 2 hours and now it is reduced to 30 minutes or so. Individuals need to occupy themselves constantly to not have time to think about it and the best way to do it is to create another life and melt in the Canadian society (Participant 7).

When asked how their mental health has impacted their daily lives participants said they

were having a difficult time concentrating at work. Participant 6 found it difficult to connect with colleagues:

I can feel the impact of trauma as I am scared when people at my work place ask me about my religion or if I am against or with the Syrian regime or any terrorist organizations. I was living in a war situation in Syria and it is not so easy to overcome this trauma. I keep having nightmares and this for sure influences my 
daily life in Canada. The trauma is still present in my life because we often check social media and communicate with our friends and family back in Syria. We are still aware of what is happening over there even if we want to forget about it. Sometimes even when they put the news on here, they talk about the war that is occurring there and I am traumatized to even look at it. In general trauma is a big barrier that almost all Syrian refugees have to deal with on daily basis. I know many people that get scared from hearing fireworks, because it reminds them of the sound of weapons back home (Participant 6).

Participant 10 stated that there was a need for Syrian refugees to have greater access to mental health services:

Syria was a country with stable economy and we mostly depended on our own natural resources. What happened in Syria destroyed our lives and nobody was expecting such chaotic situation and lasting war. We came to Canada carrying with us the fear and trauma of war even if we feel much safer here. It is not easy to disconnect from our countries of origin because we still share this pain with them. So our life here in Canada is automatically impacted by this trauma as we think about the rest of our family there. Therefore, I can qualify the trauma as another barrier that we face in Canada because it is not easy to overcome it. I spend most of time watching the TV news about Syria and the same time could be used to look for a job here in Canada. I believe that we need psychological and mental support to know how to cope with trauma and this will help us advance in our lives in Canada (Participant 10).

Although, participants stated that trauma has impacted their lives in Canada many also felt optimistic about the future, and expressed that through time and their new surroundings in Canada they have been able to improve their mental health. Participant 9 and 8 stated,

At the beginning I had no taste of life because I know that the minute I am having fun here, others are killed in Syria. I did not want to study or look for jobs and I felt so depressed. There so much trauma that we carried with us to Canada and that we have to deal with on our daily basis. Due to the fear and atrocities that we went through in Syria, my stomach feels really bad once I hear a heavy noise. Now I feel much better because I don't think about the trauma that much, because I want to have a happy life here in Canada. I try to make myself busy with studies and making new friends or spending time with my family doing outside activities (Participant 9).

Although we experienced horrible moments of war and trauma, when I came to Canada I decided to put that aside and start a new life. I want to take the positive 
aspect of life and I want to work hard here to do something good for my country, to stop the war. I feel like we are given a second chance to live, so I want this life in Canada to have a meaning and I want to help the rest of my family there as much as I can. I am now focusing on my studies and I am trying to secure my future and the one of my family (Participant 8).

A refugee's mental health is not solely dictated by their past, their new lives in Canada impact their mental well-being too. Key informants explained that they commonly saw participants experience a decline in mental health related to their employment experiences in Canada. Key Informant 1 describes deskilling as a prominent cause of distress:

Yea, (trauma) played a role. Definitely. On more then one level. Most of them are deeply depressed about leaving family members behind. This is affecting their concentration on the training of English language classes. Also, for those who are forced to go into the job market, because they are trying to help their family members back home in terms of finances, they are not focusing on their education as well, because they are working. But, for like the emotional and mental stability the major thing that they are facing in terms of employment is not working in their own field of experience or study. They are feeling like they went from a very high social position to a really low position, because here they have to start with certain jobs they never had to deal with before, so this is affecting their mental health here, like with their experience here (Key Informant 1).

\section{Limited knowledge of the Canadian Labour Market}

Inexperience with Canadian culture and norms led to confusion for many participants. Participants noted that not understanding the Canadian job market, and being unaware of the services available to them caused frustration. Further, many participants contrasted the difference between the labour market culture and norms in Canada with those in Syria. Participant 7, 5, 6, and 4 expressed these sentiments:

I think when you lack knowledge about the country's system and you do not have enough support then it is hard to find an employment. If you add to that the language barrier and the Canadian experience it justifies why I haven't found a job yet (Participant 7). 
In Canada everything differs from back home, as you need more expertise and proof of competency for most of the jobs you are applying for (Participant 5).

To be honest I was expecting to face barriers such as language. I knew it was not easy to find a qualified job from the first year (...) I did not know that there is Adult learning school where you can pursue your high school studies. If I knew about it I would have done it earlier and I would have started university in the upcoming fall (Participant 6).

You know I am newcomer, and I don't know how the lifestyle here, how the program for agency here works. In Syria we don't have agencies like this here. I thought if I go to them and I give them my resume, then they have to call me back. I thought like this, they have to call me back (Participant 4).

Participant 10 explained that he was unable to find work as a painter in Canada, because

the labour market regulations required more than just his experience. He said,

If we take for example the profession of painter, although I am very experienced, I need to go to a technical school here and get a safety training with certification. Then I will be able to work with constructors. I don't know if this will happen soon, but I am hopeful that I can go through this procedure and find a job as painter. This is completely different from Syria when we did not need any training; all we had to do is to show our competency while painting (Participant 10).

Key informants stated that they try to help newcomers become aware of the job market and Canadian culture, before they begin applying to jobs. This was done through providing resume building classes, computer training classes, practice interviews, and describing the requirements needed in order to work in certain professions. Participants stated resume building and computer training, in particular, as being very helpful for the job search. Participant 4 said,

They helped me to make a resume, because I didn't have a resume before. In Syria we have resumes but in Arabic language and its different. Different about the resume in English, just you have to write your education, your address, and your age, but here you have to write your experience, your education, your detail of address, a lot of details. In Syria we don't have like this. The agencies helped me make a professional resume talking about my experience. Now I have resume. They helped me to make email address. They said you have to have email address, 
because here everything by email. Letters by email. It's more important to have email. And I made an email address (Participant 4).

Key Informant 3 noted that initially newcomers felt disappointed when they came to seek employment support, because they were unaware of the how the process works.

However, once they became more familiar with how the employment agency would be able to support them they felt optimistic. Key Informant 3 stated,

What they want to know when they first come in is, is there a job for me, because they don't know the kind of services, how we support them, how we coach them or assist them in that job search marathon. They automatically assume, because that's the kind of services they have back home. You go to an agency they find you a job. They don't teach you the skills to find a job. They find you with the employers, the connections, the placements. Here we need to teach them the skills we help them to understand. When they come in the first thing they'll say is so what is the job? What kind of jobs do you have? So then, you need to explain this is the kind of services we have, this is how we are going to assist you. Step one we are going to take them back. They are generally disappointed in the process and how it works, but once they grasp the idea and how it is going to work out and what kind of potential employers they are going to work with, then they feel better about it. They need to see the light (Key Informant 3).

\section{Employment Support}

\section{Privately Sponsored Refugees}

Overall PSRs received far more support than GARs when searching for employment. Private sponsors helped in a variety of ways including resume building, childcare, acting as a reference, and connecting Syrians newcomers directly to employers. Private sponsors played such a vital role in the lives of sponsored refugees that participants commonly referred to their sponsor groups as their sponsor "family". Sponsor "families" can provide social capital to newcomers, making them invaluable during the job search process. Participant 7, 1, and 3 described their relationship with their private sponsors: 
My sponsoring family helped me to look for jobs. They also set up an interview for me with (an employer). I did the interview with them and I am still waiting for their response. One member of the sponsoring family helped me build my resume and cover letter while other members helped me to locate potential employers downtown and in other areas of Toronto (Participant 7).

To be honest, I received help from everyone, but I was landed to this job through a friend. But I also got help from the church that sponsored me, they introduced me to some people, other people will introduce you to other people in the connection circle and so forth (Participant 1).

Some of them (private sponsors) visit us every week. Help my children with homework, and to sign up for camps for school for our neighbourhood program and they took us anywhere, before. Now we learned to go, but they taught us how to go (Participant 3).

Participant 2 noted how her private sponsors were able to begin helping her find employment before she had even arrived in Canada:

I consider myself so lucky because I did not have to search that much to find my current job here in Canada. Six days after my arrival to Canada, I had an appointment scheduled with and agency called Access Employment. This agency told me that they will secure me a job with an Islamic school. Two weeks later, I had an interview with the Islamic school and they took me as a volunteer there. I did not even have to look for a job as everything was organized easily between my sponsoring family, the employment agency and the Islamic school... Without my sponsoring family I would not have the chance to get to the agency that way and find a job. The family played an important role in giving my resume to the agency prior to my arrival to Canada, they talked to them about my expertise and they scheduled a meeting with them once I came here (Participant 2).

Eventually, Participant 2's voluntary experience with the Islamic school turned into a full time job.

Sponsor "families" seemed to take over the role of settlement agencies in some cases. Participant 5 stated that his sponsor "family" offered him support in looking for meaningful employment. Although, he was aware that he could receive help from immigrant serving agencies, he chose not to. It may be that this participant felt that he was receiving enough support from his sponsor "family" that he did not see any value in 
going to a immigrant serving agency for help in his job search. All key informants

expressed that they were certain many PSRs were not utilizing the services of immigrant serving agencies, because their needs were being met by their sponsorship group.

Participant 5 stated,

I realize that it is difficult to find a job in Canada that matches my previous skills and expertise. My sponsor family told me if you don't like a job they will look for something different until I find something that I like. So yeah, I feel like I am pushed to do other jobs than the one I want to do... My friends told me that there are employment agencies that help people looking for jobs, I am aware of it, but I still haven't asked for specialist's help. I don't exactly know what is preventing me currently from seeking their help, but it is possible that I go see them in the future if things don't go well with my current job (Participant 5).

When asked what resources they used to find employment opportunities participants explained that having people that can refer you to jobs is the most ideal way to find work. Having a social network is particularly important for those who have limited English and computer skills, because they do not feel confident using the computer during their job search, and rely on their social network to inform them of jobs opportunities. Participant 6,5 , and 10 described their difficulties looking for work online:

While looking for a job I was asking some people that I knew directly. I found this way helpful because I got access to the information directly by the word of mouth. The same people told me that I can find jobs on Internet websites, but I was never able to go through them, because of my English level. I found difficulties understanding most of the job postings and the content of it (Participant 6).

I used a basic resource, which is asking people if there are opportunities for jobs. It is necessary to make friends in order to get help learn about the life style here in Canada. I know that many people use Internet to look for a job, but due to the language barrier I don't know how to use Internet (Participant 5).

Ifeel it is easier to make a social network that will help one day find a job. Same people also talked to me about ways of finding jobs online, but I feel that my English level plus my computer skills are so limited. Therefore, Internet is not the efficient way for the moment to look for a job (Participant 10). 
Although key informants did not want to generalize the differences between PSRs

and GARs they said that PSRs received more support overall then GARs, which might

lead to PSRs integrating into Canadian society quicker. Key Informant 1 said,

It's not a fact, because there are exceptions here and there, but basically, the privately sponsored are more settled and they are more able to adapt quickly to the culture, or like you know, to integrate into the society. Because their sponsors get them involved in all those culture things for example, fieldtrips and Christmas parties, thanksgiving, and all those things, while the government sponsored they don't have that. They just get their salary. They don't have any relationship with Canadians, or people who have lived here for so long. It does seem that the privately sponsored are more settled (Key Informant 1).

\section{Government Assisted Refugees}

All of the GARs interviewed were unemployed at the time the interviews were conducted, but some were being interviewed for work, and may be employed now. GARs showed much more independence in their job search compared to PSRs. Key informants noted that GARs, because they do not have private sponsors have the ability to make their own decisions, without interference. For example, Participant 4 began looking for employment entirely on her own without any support. She went in person to various supermarkets and completed applications, however she was unsuccessful in finding a job. All of the GARs interviewed stated difficulty finding work without support from employment agencies or friends. Using the Internet, or applying in person did not lead to job opportunities. They tried to use their social network for assistance but felt it was too limited. Participant 10 stated,

I am constantly asking the people around me that have lived here for years and newcomers for help in terms of looking for a job. Today, one of the students that I study with told me about employment agencies that can help me find a job. I was also sitting one day in Victoria Park and I saw an advertisement sign with an expression on it, but I did not understand what was written. I wrote that expression in my phone's translator app and I found out that this is for an employment agency, so for these reasons I am for sure willing to seek their help soon (Participant 10). 
GARs also expressed that they were lacking a strong social network, which made their job search challenging. Participant 8 described how knowing someone who can provide you with a referral to an employer is very valuable:

I was able to find some new people that offered help, but it is so difficult to make strong social connections that can refer you to an employer directly. I know also that in Canada it is question of referral especially for the first time when you have no Canadian experience and you need it in order to look for other jobs. I still did not find someone that has the power to refer me to a Canadian employer who will give me chance to build the required experience (Participant 8).

Participant 8 turned to an immigrant serving agency for help in finding employment, but she was critical of their services, resulting in her looking for work on her own. She said,

They were some organizations...that had Arabic speaking representative(s) that talked to us and helped us with basic services as newcomers. My parents are still in contact with them and they always seek their help when needed. I can tell that their help is limited, because they don't really help you find a job. For example, I went to see them and they told me because I am in high school and have no experience they couldn't find me a job. I had no choice than looking for a job on my own in retail and in sales (Participant 8 ).

\section{Employment Outcomes}

Ethnic bonds have played a large role in hiring the Syrian refugees interviewed.

Arab employers had hired two out of four participants. Participant 1 stated one of the reasons he was able to secure his job is because his boss is Syrian:

So basically the other two interviews that I did, the employers did not ask me for job references, because I did not reach the level of providing references in the hiring process. This guy who hired me at the end is a Syrian guy, basically he knows my friend very well and he trusts my experiences. So he did not ask me for references (Participant 1).

All employed participants are working in low-wage, entry-level positions. When asked to describe their jobs participants stated feeling pressured to take positions that did not match their skill level. They did so either, out of time constraints due to their 
sponsorship ending soon, or because they felt that they would not be able to obtain

higher-skilled jobs. Participant 1 and 2 said:

So it took me basically 10 months until I got this job, there was lots of surviving jobs in the labour market that I could have had earlier, but I was sticking to the non-for-profit sector. But when I hit the $10^{\text {th }}$ month I said it is getting very dangerous now and I need to find a job now. Basically this was the longest waiting time for a job in my life...I did not have enough time to start searching again because my sponsorship was about to expire by the middle of July. So I needed to secure a job very fast, so I was afraid to be left with no job and end up using welfare, which is something I cannot handle. So I immediately got this job and to be honest I didn't have much time to search for another job. In this country, searching for a job is a full time job, but I hope that in the future I will find something that will connect me back to my passion (Participant 1).

I believe that there are better opportunities then the one I am in now, like jobs with government and big companies. However, I know that I need to build a solid work experience and the place where I am now is a good start. I believe that it is difficult to find a job in something that I have expertise with and if the sponsoring family did not help me I would not be working here. My future goal is to work in a community center with newcomers (Participant 2).

Participants expressed a desire to work in their previous field of employment, or to work

better hours. However, they also noted feeling relief and gratitude for having found work.

Interestingly, no participants mentioned that they were discouraged by the amount they

were earning. When asked if they were satisfied with their employment Participant 1 and

5 stated:

To be honest it's not, because this is not the sector I am trying to stick with. I am 32 years old I want to be in something that I want to do and not something I am forced to do, because I need money. So that's why I am still searching for non-for profit sector, I like to work with immigrants and refugees as I did in the last six years in Syria and Lebanon and Turkey. That's what I want to do here in Canada and that's why I am not satisfied with this job. But at the end it is a job and it is good to have it now (Participant 1).

I will lie to you if I tell you that my current job is satisfactory, because I work overnight and it is difficult for me. However, I will be exaggerating if I tell you that I am not happy in this job, but after all it is a source of income (Participant $5)$. 
Surprisingly, participants who were employed or who were looking for work stated that one of the reasons they valued employment was because it allowed them an opportunity to improve their English, meet new people, and learn more about Canadian culture. No participant expressed wanting to find employment solely to make money, instead they viewed working as a way to become more integrated into Canadian society. Participant 2 and 7 noted,

I am happy with my job so far because I am learning new things and expanding my work experience. This job also allows me to learn new English vocabulary from my coworkers, which is helping me improving my language skills. I am also happy because at the end of the day I came to Canada and I was able to have a job similar to my previous one in Syria (Participant 2).

The number one goal for looking for a job is to improve my English, to get to know people and to try to adapt to the Canadian labour market (Participant 7).

Key informants explained that frontline workers try to help newcomers from being trapped in "survival work"; however, they were ambivalent about how to help Syrian refugees find work in the primary segment of the labour market. For example, Key Informant 1 stated that frontline workers encourage Syrian refugees to continue their education and improve their language skills:

We always encourage them, even if your working, focus on English so you can, for example, go into a training school, so you can change the field of work you are doing. If (they) are interested, of course. Some of them are interested in what they are doing, like construction, so we also educate them on where to get certified, like construction certificates, stuff like that. Those that are interested in staying in the construction field we try to find part time jobs for them, so they can focus on the English as well, from there, by improving their English maybe they can take some other type of training later on, because some training is only provided in the English language (Key informant 1).

However, key informants also stated that finding Syrian refugees work is their main job, which means they do encourage newcomers to take positions when the opportunity arises, even if those opportunities are low paying, dead-end jobs. Key Informant 3 
explained that she was working with a client who was contemplating accepting a job

offer. The client was deciding whether she should continue her English classes or begin working. The key informant shared that the client was encouraged to choose the job over her English classes:

She was distressed because she had a job offer. She had to make a decision about whether to take the job or stay in school. She couldn't decide, she had the children home, this was her first time working, so that was a lot of pressure for her to say okay I want to go. So what I basically suggested she try to do, we were trying to coach her into one day at a time, just go in for the first day and decided if you like it. She was a really skilled person, she had the skills, she had the willingness, she had the motivation, but then again, she was able to move onto the next level in her language class (...) She wanted to learn, she wanted to be able to communicate better, so she didn't want to give up that aspect, but she did take that job in the end, she's really happy, she's doing great. So it was a successful outcome (Key Informant 3).

Although, Key informant 3 described the client accepting the job as a "successful outcome" the key informant explained that once the refugees begin working it is difficult for them to improve their language skills, because they have limited time to attend classes. Key Informant 3 notes,

There are language classes in the evenings, but when I suggest them they (Syrian refugees) say I have four children what do I do, do I go home to be with my children for a couple of hours before they go to sleep, they have schoolwork, or do I go to class? Family comes first, you have to prioritize work and family over classes, or any other social activities you may want to participate in, so its been a real challenge for those individuals (Key Informant 3).

By coaching Syrian refugees to accept "survival work" over improving their English skills Key Informant 3 acknowledges that the client will have a more difficult time learning English. Limited English ability, as the literature review has shown, makes its harder to have upward mobility in the job market. Thus, key informants may inadvertently be making it challenging for Syrian refugees to move away from "survival 
employment" by encouraging Syrians to choose work over investing in their English language ability.

However, key informants stated that they felt unequipped, with the current employment support programs, to help newcomers find work beyond the secondary segment of the labour market. They noted that it would be more helpful to offer programs that directly connected newcomers to employment and focus more on employment outcomes, rather then job-related skills training. Key Informant 1 said,

In terms of training I would say to find more training opportunities that are not only for entry-level jobs. Usually the training is for cooking, sewing, maybe customer services or stuff like that (...) That's why I said I would prefer if there was more focus on certain kinds of training (...) The goal is to actually employ them. The goal is not only to train them like the usual settlement programs or to make them more familiar with certain skills. No, the goal is to employ them. So the agency has to find employer partners where we can say, what does this employer want? We can train them on what the employer wants and if you guarantee to employ or hire those we can work on their English language skills, if you can hire them (Key Informant 1).

\section{Future Career Goals}

Participants expressed their desires to expand their employment opportunities by continuing their education, either through improving their English skills, or upgrading their academic education. Participant 8 and 6 stated,

I would like to continue further studies in International Business Management in college. Then go to the university. I am aware that I need to continue studies in order to specialize in a field and to increase my chances to find better jobs (Participant 8).

I will start in September high school for adults to improve my English and Maths level. Once I meet the requirements I will apply for colleges and universities to continue studies in the civil engineering field (Participant 6).

When asked what their expectations were before coming to Canada most participants expressed concern due to a lack of knowledge about Canada, but were optimist when sharing experiences of their initial settlement. Participant 8 and 5 said, 
Before coming here we were worried because we did not know how the society will be. But when we came to Canada we felt safe and it looked like a good country to settle in. So far we are happy with Canada even if we have faced language barrier and lack of Canadian experience (Participant 8).

To be honest I was coming to the unknown not expecting that much. We have no family here in Canada and it makes things a bit difficult but we said that it will certainly not be worse than it was in Syria. We are happy so far with the outcome we received help for 6 months from the sponsor family and 6 months from the government. We are aware of the challenges that we are facing but we are looking forward to a bright future (Participant 5).

Furthermore, although the majority of participants in the sample are currently receiving financial assistance from Ontario's welfare program those that were unemployed noted that they were eager and excited to work and emphasized the importance of being selfreliant and independent. Thus, shattering the stereotype that individuals receiving support from the government are not willing to work, and want to remain dependent on government resources. When asked how she felt about starting a job soon Participant 4 described feeling stressed, but also eager to begin working:

I feel confident. I have a lot of stress because it's the first time I will start work in Canada, but I feel like confident, because its important to have a job here, to be responsible for yourself. You don't need any help from anybody (Participant 4).

However, although participants expressed gratitude many also stated that they were in need of more support from the government in order to achieve their goals. Participant 10 noted,

While walking in the streets here, nobody asked me where do I come from and for the first time I feel that I am a citizen here. Most of people here are friendly and willing to help which is exactly what we need. But we feel like the government is not doing that much in supporting us although they provided us with financial help the first year. We are aware that there is a bright future for our children here but we need this solid support from the start in order to build something solid (Participant 10). 
When participants and key informants were asked how they felt about the one year time frame Canada's resettlement programs provide they all responded by stating that programs should go beyond one year. Participant 4, 5, 6 noted that all Syrian refugees should not be expected to be self sustaining as certain individuals face greater barriers then others when its comes to securing employment:

For me, I can finish my language in one year, because I need to progress faster, but for example my mom she can't move to level 6 in one year, she needs two years maybe, or three years, to move to level 6 or be good at English. It depends for everybody. Maybe a lady who have 5 children, and she goes to school everyday, and she have to take children to school and to bring them from school and she needs more time I think, but for me I am free I don't have any responsibility. Maybe it will be faster for me, but for other people its different (Participant 4).

I would say not less than 3 years of course it varies between individuals. I would state that again, the language and competencies will play a fundamental role in having people adapted to the Canadian life style. The more they are competent and proficient the faster they adapt. I have a friend that is a journalist here. I knew him back home in Syria and he was a journalist too with excellent English. So he was able to secure the job within his first few months. As per my situation I came here in 1 year and half ago and I feel that I am still struggling to adapt to the life here and understand the labour market system (Participant 5).

When it comes to looking for a job, it is very important to make social connections with the people of your community. I believe that it takes two years at least to adapt to the Canadian life style and to understand the labour market. In the first year you face many barriers such as language, weather conditions and social integration. In the second year you start understanding all those barriers and cope with them (Participant 6).

Key Informant 1 stated that immigrant-serving agencies might have been overly optimistic about being able to prepare Syrian refugees for the labour market within one year:

Everyone was optimistic, but now this is what I realize: it's totally not enough (time) and maybe this is a learned lesson for other refugees in the future. It's too difficult. The settlement process is so difficult. They will not focus on English. Especially this kind of culture, like Middle Eastern culture, they have a lot of kids, and it's hard for them to learn the language or even focus on whatever they need 
in order to prepare themselves for the job market within the first year. Some of them had to go on the waiting list for English classes for three or four months so they lost almost half of that year, because they are on the waiting list. It wasn't enough to prepare them to go into the job market (Key Informant 1). 


\section{Discussion}

The interviews provided great insight into how some Syrian refugees have been navigating the labour market a year after they first arrived in Canada. The barriers to employment participants described align with those found in the literature. Lack of fluency in English, lack of Canadian experience, poor mental health, and learning about the Canadian labour market were the most frequently stated challenges participants and key informants described. Human and cultural capital theories provide an analytical lens on the barriers Syrian newcomers encountered entering the labour market. Social capital theory can illuminate the advantages that PSRs had compared to GARs regarding employment support, particularly Coleman's (1988) explanation of information and social capital, and Putman's (2000) writings on bridging and bonding social capital. Further, segmented labour market theory accurately describes the employment outcomes of Syrian refugees interviewed, as all employed participants hold position that can be categorized as "survival work". Lastly, Syrian refugees stated a desire to expand their employment opportunities through schooling, and language training; however, they noted that more assistance from the government was needed to help with their economic integration. The government's current resettlement assistance programs offer a tight oneyear timeframe and limited financial support to Syrian refugees. These programs unify a diverse collective of individuals and expect all Syrian refugees to have the same result, be financially self-sustaining after one year in Canada. By doing so, these programs do not address the varying needs of Syrian refugees.

Grondin (2005) states, "when immigrants arrive in a new country, their ability to

express themselves in the official language or languages of that country can have a major 
impact on how successfully they integrated" (p.7). Language ability is one of the main components of human capital and is "undeniably a major economic asset" (Grondin, 2005, p.7). Boyd and Cao (2009) found that immigrants with poor host country language skills earn less than those who are proficient in English and/or French. Language was emphasized as being the predominant challenge Syrian refugees encounter while looking for employment. The findings show that language, as a barrier is more complex then it may seem. Firstly, not being fluent in English discounted any previous work or educational experience a newcomer had. As such, many participants stated that language was their only obstacle in finding employment. After they had improved their language skills they felt that they could very easily find work. Although, this may not be a realistic expectation it indicates that newcomers view learning English as being very valuable. These findings parallel Grondin's (2007) research on immigrants and language in Canada. In Grondin's research 96\% of immigrants surveyed stated it was "very important" to learn or improve their English skills. Furthermore, Syrian refugees who were employed stated the main reason they were able to find work was due to their language ability. Secondly, newcomers face different challenges while trying to learn a new language. For example, those who arrived in Canada and were assessed at a CLB level 3 or higher were able to improve their language skills much faster then those who had lesser fluency in English. The first year of settlement is difficult as newcomers are having many new experiences making it difficult to concentrate on language classes. Having children and being of older age appeared as the two main factors that made it challenging for participants to prioritize learning English. Moreover, many participants noted LINC classes were much more than an opportunity to improve their English. 
Instead they served as a way to make friends, learn about volunteer opportunities and immigrant serving agencies, as well as potential employers. Thus, LINC classes help Syrian refugees build social capital, because they act as, what Coleman (1988) describes, "information channels" for Syrians to gather information that would lead to action. Action in this case would be accessing the labour market. Therefore, not attending LINC classes may be a double penalty: newcomers lose the opportunity to invest in their human capital, by improving their English skills, and miss the chance to make social connections that can pass on valuable knowledge about entering the workforce.

Participants stated employers often cite lack of Canadian experience as reason for not hiring them. Lack of Canadian work experience has been well researched as being a primary barrier for all immigrants accessing the labour market (Reitz, 2007; Ferrer \& Riddell, 2008; Frank, 2013). While, Syrian refugees did voluntary work as a way to gain Canadian work experience it did not prove to be very effective. As Participant 9 pointed out employers showed more interest in Canadian work experience rather then volunteer experience. Thus, limiting the value of their volunteer work, in regards to finding employment. Surprisingly, contrary to the literature participants did not explicitly state unrecognized foreign credentials as being a major barrier to finding employment. Instead, most participants accepted that their foreign credentials would be unrecognized, and decided to focus on challenges that they could more easily be overcome like learning English. This outcome may have been different if the sample size included "highly skilled" participants. As immigrants in professional occupations such as "science and engineering, health science, education, and social- science related fields" have lower 'return to human capital'; returns in this case meaning "the premium available in the 
labour market for...educational qualifications and work experience" (Reitz, 2007, p.20).

One of the biggest divergences between other immigration categories and refugees can be their mental health. Yu et al. (2007) note that the refugee experience can be very traumatic, which make refugees a more vulnerable population compared to other immigrant groups. Becker (1962) states, "one way to invest in human capital is to improve emotional and physical health", as an individuals poor overall health, including mental health, is "considered an important determinant of earnings" (p. 27). Participants described how experiencing conflict in Syria had negatively impacted their overall wellbeing and the ways in which that effected their employment experiences. One participant stated his mental health prevented him from beginning his job search, because he was feeling "depressed" (Participant 9). Many described being able to "feel the impact of trauma" (Participant 6) in their daily life, including at work. One participant found it difficult to connect with colleagues at work, because he was fearful when asked questions about his personal life, concerning religion, or political views on the situation in Syria. Furthermore, many found it difficult to concentrate or focus at work, because they were concerned about their family and friends currently living in Syria, or afraid of learning about new updates in Syria.

Interestingly, when key informants were asked how they have seen trauma impact Syrian refugees and their employment experiences they focused more on the difficulties newcomers encounters in Canada and less on how their experiences in Syria might be affecting them. This may have been the case because the key informants interviewed were not mental health counselors instead their expertise was in providing employment counseling for Syrian newcomers. Similar to what the literature has shown, key 
informants stated unemployment has a negative impact on the mental health of Syrian refugees. However, not having meaningful employment, work that does not commensurate with one's training and education, was stress inducing for newcomers as well. For example, Participant 1 and 2 described being frustrated with their current occupations, due to deskilling. Hynie and Changoor (2016) note that lacking meaningful employment can lead to poor health outcomes as well, particularly if the work is physically demanding.

The last barrier to employment noted by participants was that lacking knowledge of how the Canadian labour market functions hindered their employment experiences. This indicates a lack of cultural capital, particularly what Bordieu (1986) describes as embodied capital, as Syrian refugees lack knowledge of the behaviours embedded into Canada's labour market. For example, participants stated not understanding the job search process, such as the importance of having a resume or an email address to provide to employers, prior to seeking employment counseling at immigrant serving agencies. Likewise, they expressed surprise over the regulations involved with beginning a trade job, like painting. These gaps in knowledge can limit the access newcomers have to better employment and education opportunities (Creese \& Weibe, 2012). As, Participant 6 stated he wished he had known that he could attend and adult learning centre earlier, because he would have applied much sooner. Bauder (2005) describes this challenge as a "lack of cultural competence" (p.94). He states that, "the unfamiliarity with the rules of the Canadian labour market is an important employment barrier for newcomers... this barrier is highly contingent on place of origin and immigrant class" (Bauder, 2005, p.94). Syrian refugees interviewed often compared the differences between Canadian and 
Syrian hiring and workplace practices and described them as being quite different.

Furthermore, as Syrian refugees arrived as refugees, compared to other immigration categories, they might not have been as familiar with Canadian labour market norms as, for example, skilled workers who have planned and, possibly, researched the Canadian labour market before making the decision to emigrate to Canada.

The most notable difference between PSRs and GARs was seen in the employment support section, as the different refugee programs offer varying degrees of social capital. The findings are in agreement with the literature in so far that PSRs have better employment outcomes then GARs. Out of the ten participants interviewed the four who had found employment were PSRs. No GARs interviewed were able to secure work. The findings show that employment opportunities were largely dependent on the amount of social capital Syrian newcomers were able to accumulate thus far. Private sponsors were able to assist PSRs during their job search through multiple ways: directly referring them to an employer, acting as a reference, helping build resumes, or connecting the PSR with an immigrant serving agency. In this way, PSRs have an advantage compared to GARs, because they have a group of Canadians ready and, typically, eager to support them find work. Thus, they have already accumulated social capital before even setting foot in the country. PSRs stated that their sponsors greatly helped accelerate the job search process. For example, as Participant 2 shared her private sponsors had already begun circulating her resume before she even arrived in Canada. As such, the relationship between Syrian refugees and private sponsors can be described as bridging capital. Through their private sponsors PSRs are able to build relationships with Canadians from a variety of different socio-economic and ethnic backgrounds. Meanwhile, GARs relied 
on other means to build social capital, and found more success in securing bonding capital with other immigrants, and Syrian refugees they met. They did so mainly through attending English classes, where they have the opportunity to meet other newcomers, and by connecting with immigrant serving agencies that could refer them to employers. Bridging capital was more useful than bonding capital in securing employment as bonding capital is less likely to provide new information and resources helpful in finding work; while, bridging capital connects people with diverse socio-economic backgrounds, which is more likely to result in the sharing of important information that could improve one's economic opportunities (Briggs, 1998).

Perhaps the most significant advantage that PSRs have is that they do not need to spend a large amount of time accumulating social capital for themselves. The Canadian government's website states that private sponsors must assist refugees financially, emotionally, and socially. Thus, private sponsors may end up very quickly becoming largely involved in their sponsors' lives. PSRs described their private sponsors as their sponsor "families". Indicating that sponsor groups and PSRs create strong ties that parallel those of real families. The time it may take a GAR, who does not know speak any English, nor know any Canadians prior to arrival to build the same type of close-knit relationship would presumably be far longer.

However, GARs showed more independence as they sought out employment opportunities by themselves, and created their own social capital. Although, independence came at a cost as GARs did mention actively seeking out individuals that could refer them to employment, because searching for work on their own was not resulting in employment. 
Syrian refugees also found employment opportunities by relying on ethnic bonds. Co-ethnic social capital was particularly advantageous as Arab-speaking businesses were able to hire Syrian refugees, regardless of their fluency in English. Arab employers hired 2 out of 4 employed participants, and 1 participant was hired, because a Syrian employee who was already working at the business referred him. Li (2004) states that ethnic connectedness can be helpful to its members, because it produces group solidarity. However, " ethnic connectedness comes with a cost in terms of reduced opportunities in the open job market due to lack of connections and contacts in mainstream society, as well as in terms of accentuating social distinctiveness" (Li, 2004, p.178). This can help to explain the employment outcomes of Syrian refugees interviewed as many occupy similar customer-service, administrative, entry-level positions.

Unfortunately, the employment outcomes of the Syrian refugees interviewed are not surprising. Segmented labour theory shows that immigrants are far too often, delegated to the bottom of the labour market hierarchy. Interestingly, immigrant-serving agencies showed a great deal of ambivalence regarding Syrian refugees' job opportunities, which may be pushing Syrians into "survival work". Although, settlement agencies are aware that "survival work" is not ideal, and try their best to find better types of employment opportunities for their clients, at the same time they also state that finding employment for newcomers is one of their main objectives; which implies, that work is better then no work, regardless if it is "survival work". For example, key informants explained that immigrant serving agencies make sure to encourage Syrian refugees to continue improving their language skills, even if they are employed, so they could, if they chose, attend educational or trade institutions to improve their future employment 
opportunities. However, as Key Informant 3 explained, they also encouraged newcomers to accept employment opportunities like "survival jobs" over attending full time English classes. Although, it might seem like a sensible step to help newcomers become employed as soon as possible, key informants did note that accepting "survival work" could limit a newcomer's future employment opportunities, as it may stunt their human capital. Key informants acknowledged that once newcomers begin working full time, they typically stop accessing settlement services, like language classes, as they become too busy with work and other obligations, like family responsibilities. This greatly diminishes their chances of attending post-secondary educational institutions as well. Thus, inadvertently service providers may be leading newcomers to be stuck in the lower tiers of the labour market, by encouraging them to take any job that comes their way. Segmented labour market theorists argue that workers in the secondary segment of the labour market will most likely remain there, because it is very difficult, particularly for immigrants, to move from the secondary segment to the primary segment of the labour market (Peck, 1996).

However, other factors influence newcomers to accept "survival jobs" as well. For one, newcomers may panic as they approach the end of their first year, as their financial assistance stops, and out of financial pressure accept "survival employment." Also, key informants stated that it was difficult to find employers that offered jobs that had upward mobility, good wages, and benefits. Thus, making it so that settlement agencies could typically only connect immigrants with "survival work". This may be due to employers, as well as professional associations, devaluing immigrants' education and work experience, and viewing immigrants as suitable for only "survival work": "The 
failure to recognize foreign credentials helps stream immigrants into low wage employment, and lack of clear mechanisms to bridge international and Canadian degrees in various professions helps keep them there" (Creese \& Weibe, 2012, p.60).

Regardless, of their current difficulties with their employment experiences participants stated being optimistic about their future in Canada. Many noted wanting to go back to school, while others sought to improve their language skills. Furthermore, participants broke down stereotypes that come with connotations of the word "refugee." Often times the word refugee is associated with descriptors such as "needy" and "desperate" in the Canadian media (Tyyskä, Blower, DeBoer, Kawai \& Walcott, 2017). All participants expressed gratitude, and either a desire to find employment that could support themselves and their families, as well as contribute in a meaningful way to Canadian society, or a focus on improving their English, and upgrading their educational qualifications to work in their previous or intended occupations. Moreover, although some participants were not happy with their employment, and the six out of ten participants are having difficulty securing jobs they all showed a great amount of resilience and perseverance for bettering their own, and their family's lives. However, although excited about their new lives in Canada, key informants and participants expressed that Canada's resettlement programs should be extended beyond one year. All interviewees stated that one year was not enough time for the majority of Syrian refugees to become prepared for the labour market, because of the aforementioned challenges involved with finding employment. The resettlement assistance program in Canada can be extended beyond one year, but only for extreme cases, and is rarely done. Instead, Syrian refugees have turned to social assistance from the Ontario government for 
continued financial support. The resettlement programs view the newly arrived Syrian population as a monolithic group as they expect Syrians to achieve the same outcomes, find jobs that offer a livable wage, within a set timeframe of one year. Tens of thousands Syrians resettled in Canada, they came with diverse educational, linguistic, employment, and family backgrounds it is only fair to expect that their labour market experiences will vary. The findings show that human capital plays a large role in employment outcomes and should be considered when looking at settlement outcomes and determining the amount of support a Syrian refugee receives. 


\section{Conclusion and Recommendation}

In sum, the employment outcomes for Syrian refugees in the GTA can be described as "survival work." The educational, professional, and skills backgrounds of the Syrian refugees interviewed were mostly considered meaningless in their job search. While the majority if Syrian refugees interviewed are still looking for jobs, two out of four participants that are employed express dissatisfaction with their current employment, due to deskilling. Overall, PSRs had a better rate of being employed, while GARs showed more independence during the job search process. Private sponsors proved to be very advantageous for PSRs, in regards to finding work, although it still led to employment in the secondary segment of the labour market. Syrian refugees stated wanting to improve their language, and receive educational upgrading so they could one day work in their previous professions, or continue to pursue the same goals they had in Syria. Participants showed a great deal of resiliency and gratitude, but expressed shortcomings with the one-year timeframe offered by the resettlement assistance programs.

Based on the interviews with Syrian refugees and key informants and the literature three recommendations have been noted. Firstly, settlement services should work with employers to develop training opportunities that are directly connected to the positions employers are willing to offer to refugees. This is advantageous because it would result in the burden not being on employers to train individuals, and perhaps allow a greater range of employers to be interested in hiring newcomers. More so, settlement agencies would be able to allocate their resources towards employment services that would result in actual employment outcomes, instead of solely training opportunities. 
Second, Syrian refugees should be viewed as individuals with varying human capital. Instead they are lumped together by the different resettlement programs and expected to achieve similar results within a set timeframe. Those who experience more challenges finding employment should be offered greater and specialized support that fit their unique and individual needs, either financially or through targeted services. Lastly, resettlement of refugees needs to be viewed as a lifelong process. As mentioned the arrival of Syrian refugees to Canada was highly publicized and Canadians were applauded internationally for their humanitarianism. However, the initial phase of settlement is just a part of the settlement journey. The interviews have demonstrated offering support and assistance for one year is not long enough to ensure successful economic integration.

Further research is needed to explore the various nuances of Canada's resettlement of Syrian refugees, and how to greater promote economic integration. A long-term study that follows the employment trajectory of this population would be interesting. Important factors to consider include how language skills have improved over time, and if there is upward economic mobility. Research focusing on improving Canada's resettlement assistance program is important, as future refugee crises will arise, most notably among environmental refugees. Most estimates indicate that, before 2050, between 100 and 250 million people will be displaced for environmental reasons (McAdam, 2009). The majority of the countries affected by this will be from the Global South, leaving countries like Canada as most capable to help. The consequences of climate change will lead to the largest refugee crisis to date (McAdam, 2009). As Canada has historically offered humanitarian assistance through resettlement it is vital that it is prepared to offer the most effective and efficient support possible. 


\section{References}

Ager, A., \& Strang, A. (2008). Understanding integration: A conceptual framework. Journal of Refugee Studies, 21(2), 166-191.

Aydemir, A. (2011). Immigrant Selection and Short-Term Labor Market Outcomes by Visa Category. Journal of Population Economics, 24(2), 451-475.

Barbour, R. S. (2008). Introducing qualitative research: A student's guide to the craft of doing qualitative research $\mathrm{SAGE}$.

Bauder, H. (2003). "Brain abuse", or the devaluation of immigrant labour in canada. Antipode, 35(4), 699-717. doi:10.1046/j.1467-8330.2003.00346.x

(2005). Habitus, rules of the labour market and employment strategies of immigrants in Vancouver, Canada. Social \& Cultural Geography, 6(1), 81-97.

Bauder, H., \& Jayaraman, S. (2014). Immigrant workers in the immigrant service sector: segmentation and career mobility in Canada and Germany. Transnational Social Review, 4(2-3), 176-192.

Becker, G. S. (1994). Human capital revisited. In Human Capital: A Theoretical and Empirical Analysis with Special Reference to Education (3rd Edition) (pp. 1528). The University of Chicago Press. 
(2007). Health as Human Capital: Synthesis and Extensions. Oxford Economic Papers, 59(3), new series, 379-410.

Beiser, M. (2003). Sponsorship and resettlement success. Journal of International Migration and Integration / Revue De l'Integration Et De La Migration Internationale, 4(2), 203-215. doi:10.1007/s12134-003-1033-z

Berti, B. (2015). The Syrian refugee crisis: Regional and human security implications. Strategic Assessment, 17 (4), 41-53.

Bevelander, P., \& Pendakur, R. (2014). The Labour Market Integration of Refugee and Family Reunion Immigrants: A comparison of outcomes in Canada and Sweden. Journal of Ethnic and Migration Studies, 40(5), 689-709.

Bourdieu, P. (1986). The forms of capital Handbook of theory and research for the sociology of education (pp. 241-258). R.(1974). The Power Broker: Robert Moses and the Fall of New York.

Boyd, M., \& Cao, X. (2009). Immigrant language proficiency, earnings, and language policies. Canadian Studies in Population, 36(1-2), 63-86. 
Boyd, M., Pikkov, D. (2005). Gendering Migration, Livelihood and Entitlements: Migrant Women in Canada and the United States, In Occasional Paper: United Nations Research Institute for Social Development.

Brar, V. (2016). Using Bourdieu's Theory of Practice to Understand Academic Under Achievement Among Inner- City Students in British Columbia: A Conceptual Study (Master's Thesis, Simon Fraser University, British Columbia, Canada). Retrieved from http://summit.sfu.ca/item/16133.

Briggs, X.S. (1988). Brown kids in white suburbs: Housing mobility and the many faces of social capital. American Journal of Political Science, 41, 999-1023.

Carling, J., Erdal, M., \& Ezzati, R. (2014). Beyond the insider-outsider divide in migration research. Migration Studies, 2(1), 36-54.

CBC News (2016). "25,000 $0^{\text {th }}$ Syrian refugee lands in Canada.” Retrieved from http://www.cbc.ca/news/Canada/montreal/25-000th-syrain-refugee-landsin-Canada-13467886

Citizenship Immigration Canada (CIC). (2017, February 09). \#WelcomeRefugees: Key Figures. Retrieved July 3, 2017, from http://www.cic.gc.ca/english/refugees/welcome/milestones.asp 
Clairmont, D., Apostle, R., \& Kreckel, R. (1983). The Segmentation perspective as a Middle-range Conceptualization in Sociology. Canadian Journal of Sociology/Cahiers canadiens de sociologie, 8(3), 245-271.

Colborne, M. (2015). Syrian refugees' mental health is top priority. CMAJ : Canadian Medical Association Journal = Journal De l'Association Medicale Canadienne, 187(18), 1347. doi:10.1503/cmaj.109-5183

Coleman, J. (1988). Social Capital in the Creation of Human Capital. The American Journal of Sociology, 94, S95.

Creese, G., \& Wiebe, B. (2012). 'Survival employment': Gender and deskilling among African immigrants in Canada. International Migration, 50(5), 56-76.

Denscombe, M. (2007). The good research guide: For small-scale social research projects / Martyn Denscombe. (3rd. ed., Open UP study skills).

Ferrer, A.M., Riddell, W.C. (2008). Education, Credentials, and Immigrant Earnings. Canadian Journal of Economics, 41(1), 186-216.

Frank, K. (2013). Immigrant employment success in Canada: Examining the rate of obtaining a job match. International Migration Review, 47(1), 76-105. doi:10.1111/imre.12014 
Girard, E. R., \& Bauder, H. (2007). Assimilation and exclusion of foreign trained engineers in Canada: Inside a professional regulatory organization. Antipode, 39(1), 35-53.

Grondin, C. (2007). Knowledge of official languages among new immigrants: How important is it in the labour market? Statistics Canada, Special Surveys Division.

Hassan, G., Ventevogel, P., Jefee-Bahloul, H., Barkil-Oteo, A., \& Kirmayer, L. J. (2016). Mental health and psychosocial wellbeing of Syrians affected by armed conflict. Epidemiology and Psychiatric Sciences, 25(2), 129-141.

Hynie, M. \& Changoor, T. (2016). Employment pathways for refugees, Part 1: Barriers on the pathway to a good job and the importance of getting there. Canadian Diversity, Special Issue: Refugee Pathways, 13(2), 31-35.

Immigration, Refugees, and Citizenship Canada (IRCC). (2017). “Canada- Syrian refugee Settlement Service Clients by Province/Territory and Census Metropolitan Area (CMA) of Settlement Provider Organizations, and Immigration Category, November $4^{\text {th }}, 2015$ - November $30^{\text {th }}, 2016^{\prime \prime}$. Accessed at http://open.canada.ca/data/en/dataset/01c85d28-2a81-4295-9c06$4 \mathrm{af} 792 \mathrm{a} 7 \mathrm{c} 209$ 
Kim, H. H. (2017). Of bonding and bridging: Ethnic social capital and contingent employment among immigrant women in Korea. Asian and Pacific Migration Journal, 26(2), 181-205. doi:10.1177/0117196817701456

Labman, S. (2016). Private sponsorship: complementary or conflicting interests?. Refuge: Canada's Journal on Refugees, 32(2), 67-80.

Li. P.S. (2004). Social capital and economic outcomes for immigrants and ethnic minorities. Journal of International Migration and Integration/Revue de l'integration et de la migration internationale, 5(2), 171-190.

(2008). The role of foreign credentials and ethnic ties in immigrants' economic performance. Canadian Journal of Sociology, 33(2), 291-310.

Lusis, T., \& Bauder, H. (2010). Immigrants in the labour market: transnationalism and segmentation. Geography Compass, 4(1), 28-44.

McCallum, J. (2016). Resettling Syrian Refugees: A National Project. Canadian Diversity, Special Issue: Refugee Pathways, 13(2), 7-10.

Magnet. (2017). Syrian Refugees: Understanding the Depth of Highly Skilled Talent (pp. 1-20, Rep.). 
Malcom, C. (2017, June 12). Privately-sponsored Syrian refugees more likely to find work: Document. Toronto Sun. Retrieved July 3, 2017, from Privatelysponsored Syrian refugees more likely to find work: Document

Mas, S. (2015). Canada to resettle 10,000 more Syrian refugees over 3 years. Retrieved from http://www.cbc.ca/news/politics/canada-to-resettle-10000-more-syrain-refugees-over-3-years-1.2892652

McAdam, J. 2009. Environmental Migration Governance. Sydney: University of New South Wales.

McMillan, J., \& Wergin, J. (2006). Understanding and evaluating educational research. Boston, MA: Pearson.

McIsaac, E. (2003). Nation building through cities: A new deal for immigrant settlement in Canada. Ottawa: Caledon Institute of Social Policy.

Montgomery, R. (1986). The Economic Adaptation of Vietnamese Refugees in Alberta: 1979-84. International Migration, 24(4), 749-768.

Moussa, I. (2014 ). Identity Crisis in the Syrian Society during the Crisis. Thesis for Executive Master in Psychosocial Support \& Dialogue . IOM and Lebanese University: Beirut. 
Neuman, L. (2006). Social Research Methods: Qualitative and Quantitative Approaches. New York: Pearson Education Inc.

Neuwirth, G., \& Clark, L. (1981). Indochinese refugees in Canada: Sponsorship and adjustment. The International Migration Review, 15(1/2), 131-140.

Peck, J. (1996). Work-place: The social regulation of labor markets. Guilford Press.

Putnam, R. (2000). Bowling alone: Collapse and revival of American community. New York: Simon \& Schuster.

Puzic, S. (2017, April 24). Record number of refugees admitted to Canada in 2016, highest since 1980. Retrieved June 28, 2017, from http://www.ctvnews.ca/canada/record-number-of-refugees-admitted-tocanada-in-2016-highest-since-1980-1.3382444

Reitmanova, S., \& Gustafson, D. L. (2009). Mental health needs of visible minority immigrants in a small urban center: recommendations for policy makers and service providers. Journal of Immigrant and Minority Health, 11(1), 46-56.

Reitz, J. (2007). Immigrant employment success in Canada, part I: Individual and contextual Causes. Journal of International Migration and Integration / Revue 
De l'Integration Et De La Migration Internationale, 8(1), 11-36.

doi:10.1007/s12134-007-0001-4

Roth, W. D., Seidel, M. D. L., Ma, D., \& Lo, E. (2012). In and Out of the Ethnic Economy: A Longitudinal Analysis of Ethnic Networks and Pathways to Economic Success across Immigrant Categories. International Migration Review, 46(2), 310-361.

Shakya, Y. B., Guruge, S., Hynie, M., Akbari, A., Malik, M., Htoo, S. \& Alley, S. (2012). Aspirations for higher education among newcomer refugee youth in Toronto: Expectations, challenges, and strategies. Refuge: Canada's Journal on Refugees, 27(2), 65-78.

Shields, J. (2003). No safe haven: Markets, welfare, and migrants CERIS: The Ontario Metropolis Centre.

Tyyskä, V., Blower, J., DeBoer, S., Kawai, S., \& Walcott, A. (2017). The Syrian Refugee Crisis in Canadian Media.

United Nations News Centre. (2017, March 14). Syria 'worst man-made disaster since World War II' - UN rights chief. Retrieved April 03, 2017, from http://www.un.org/apps/news/story.asp?NewsID=56349\#.WNq_dBRvqf4 
United Nations High Commission for Refugees (UNHCR). (2015).“Syrian Regional Refugee Response Inter-agency Information Sharing Portal.” UNHCR. http://data.unhcr.org/syrianrefugees/regional.php .

Waldinger, R. (1995). The 'other side' of embedded ness: A case-study of the interplay of economy and ethnicity. Ethnic and Racial Studies, 18(3), 555-580.

WHO. (2014). Mental Health: A State of Well-Being. Available at http://www.who.int/features/factflies/metal_health/en/

Wilkinson, L. (2008). Labor Market Transitions of Immigrant-Born, Refugee-Born, and Canadian-Born Youth. Canadian Review of Sociology/Revue canadienne de sociologie, 45(2), 151-176.

Winter, E. \& Zyla, B. (2016). Pathways into the Syrian Refugee Crisis and some Escape Routes Out. Canadian Diversity, Special Issue: Refugee Pathways, 13(2), 10- 16.

Yu, S., Ouellet, E., \& Warmington, A. (2007). Refugee integration in Canada: A survey of empirical evidence and existing services. Refuge, 24(2), 17. 